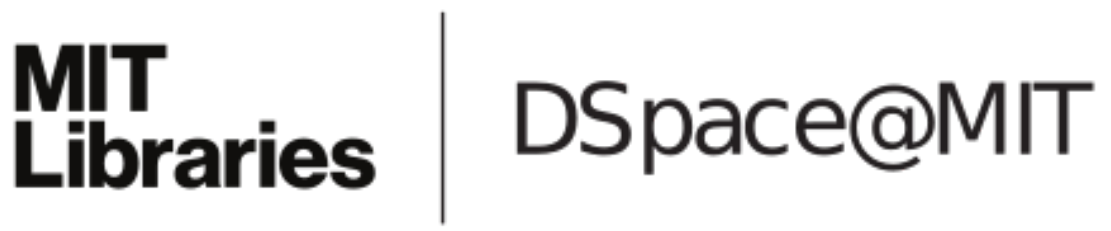

\author{
MIT Open Access Articles \\ Operando Gas Monitoring of Solid \\ Electrolyte Interphase Reactions on Lithium
}

The MIT Faculty has made this article openly available. Please share how this access benefits you. Your story matters.

Citation: Hobold, Gustavo M., Aliza Khurram and Betar M. Gallant. "Chemistry of Materials" Chemistry of Materials, vol. 32, no. 6, 2020, pp. 2341-2352 @ 2020 The Author(s)

As Published: https://dx.doi.org/10.1021/acs.chemmater.9b04550

Publisher: American Chemical Society (ACS)

Persistent URL: https://hdl.handle.net/1721.1/125667

Version: Final published version: final published article, as it appeared in a journal, conference proceedings, or other formally published context

Terms of use: Creative Commons Attribution 4.0 International license 


\title{
Operando Gas Monitoring of Solid Electrolyte Interphase Reactions on Lithium
}

\author{
Gustavo M. Hobold, Aliza Khurram, and Betar M. Gallant*
}

Cite This: Chem. Mater. 2020, 32, 2341-2352

Read Online

ABSTRACT: Formation of stable solid electrolyte interphases (SEI) that protect $\mathrm{Li}$ against continuous electrolyte reduction is one of the remaining challenges to enable safe, secondary high-energy Li batteries with minimal capacity loss. However, SEI formation pathways remain difficult to experimentally pinpoint, even with the most well-known carbonate electrolytes and graphite anodes, and especially on Li. Using a custom electrochemical cell coupled to a gas chromatograph (GC), dynamic gas-phase signatures of interphase reactions during a first Li plating step in EC/DMC were monitored as a function of cell chemistry and operational parameters. The operando nature of these experiments allows distinction to be drawn between gases formed chemically by the reaction of metallic $\mathrm{Li}$ and electrolyte, vs those evolved

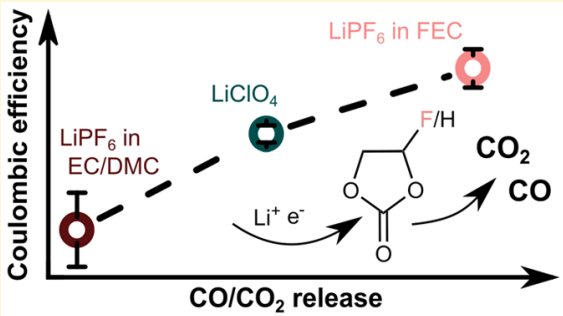
electrochemically, i.e., through electron-transfer and reaction with $\mathrm{Li}^{+}$. Quantification of gas evolution molar ratios during cycling enables determination of specific interphase reactions and their branching ratios dominating active SEI formation. We find that SEIrepair mechanisms are sensitive to the choice of the electrolyte salt $\left(\mathrm{LiPF}_{6} / \mathrm{LiClO}_{4} / \mathrm{LiTFSI}\right)$, solvent fluorination, and current density. In particular, SEIs resulting from solvent decarbonylation and/or decarboxylation-leading to enhanced $\mathrm{CO}$ and/or $\mathrm{CO}_{2}$ evolution-are the most stable, providing a simple and descriptive gas-phase signature indicative of high Coulombic efficiencies of Li plating/stripping.

\section{INTRODUCTION}

Lithium metal is arguably the most promising negative electrode for use in next-generation, high-energy density batteries owing to its theoretical capacity of $3860 \mathrm{mAh} / \mathrm{g}$ vs $372 \mathrm{mAh} / \mathrm{g}$ in graphite. ${ }^{1,2}$ However, due to its low thermodynamic potential, $\mathrm{Li}$ is reactive toward all aprotic electrolytes, which undergo reduction on $\mathrm{Li}$ to form a solid electrolyte interphase (SEI). ${ }^{3,4}$ The resulting native SEI is a thin $(\sim 50 \mathrm{~nm})$, electronically blocking, $\mathrm{Li}^{+}$-conductive and multiphasic film. ${ }^{5}$ Although different models have been proposed to describe the SEI microstructure and spatial distribution of phases, the general understanding is that the SEI is composed of an inner layer dominated by fully reduced, inorganic products (e.g., $\mathrm{LiF}, \mathrm{Li}_{2} \mathrm{O}$ ) closer to $\mathrm{Li}$ and another layer dominated by less-reduced organic species (e.g., $\mathrm{ROCO}_{2} \mathrm{Li}, \mathrm{R}=\mathrm{CH}_{3}, \mathrm{HOCH}_{2} \mathrm{CH}_{2}, \mathrm{LiOCO}_{2} \mathrm{CH}_{2} \mathrm{CH}_{2}$ ) closer to the electrolyte. ${ }^{3} \mathrm{~A}$ good SEI, in addition to supporting homogeneous and unimpeded $\mathrm{Li}^{+}$flux, must also be mechanically tough to accommodate large volume changes and minimize the rough $\mathrm{Li}$ deposits and pits formed upon plating and stripping. ${ }^{6}$ However, the native SEI formed in nearly all electrolyte systems known to date is unable to adequately protect $\mathrm{Li}$, resulting instead in continuous electrolyte consumption and capacity loss. Given its highly electrolyte-specific nature, substantial efforts have therefore focused on exploring new electrolyte chemistries and/or additives in pursuit of a better SEI that can enable long-term cycling. ${ }^{7-9}$ However, fundamental understanding is still needed regarding the reaction mechanisms by which the interphase forms and evolves, so that design of better electrolyte and SEI systems is supported from a guided, rather than trial-and-error, approach.

Most formulations of carbonate-based electrolytes used in $\mathrm{Li}$-ion and $\mathrm{Li}$ batteries use a cyclic carbonate, like ethylene carbonate (EC), in combination with a linear carbonate, such as dimethyl carbonate (DMC) or diethyl carbonate (DEC). Despite their similar thermodynamic reduction potentials $(\sim 0.1-0.5 \mathrm{~V}$ vs $\mathrm{Li}),{ }^{10}$ it is generally believed that $\mathrm{EC}$ is preferentially reduced in these carbonate blends to form the SEI. ${ }^{7,11}$ In contrast, the linear carbonate plays an important role in enhancing ion transport in the liquid phase. ${ }^{4}$ Over the past decades, a number of techniques have been used to indirectly probe formation, evolution, and breakdown of the SEI, most of which involve ex situ observation of the resulting products of electrolyte reduction reactions. For example, using Fourier transform infrared spectroscopy (FTIR) and X-ray photoelectron spectroscopy (XPS) to probe postcycled Li and graphite anodes, Aurbach et al. ${ }^{12-14}$ showed that carbonate solvents like EC reduce through a single-electron pathway

Received: November 4, 2019

Revised: February 23, 2020

Published: February 24, 2020 
toward a highly organic SEI abundant in semicarbonates $\left(\mathrm{ROCO}_{2} \mathrm{Li}\right)$. These phases include lithium methyl carbonate (LMC, $\mathrm{C}_{2} \mathrm{H}_{3} \mathrm{O}_{3} \mathrm{Li}$ ), lithium ethylene monocarbonate (LEMC, $\mathrm{C}_{3} \mathrm{H}_{5} \mathrm{O}_{4} \mathrm{Li}$ ), and lithium ethylene dicarbonate (LEDC, $\left.\mathrm{C}_{4} \mathrm{H}_{4} \mathrm{O}_{6} \mathrm{Li}_{2}\right) .{ }^{12-18}$ These semicarbonates were proposed to then further react with the electrolyte, resulting in enrichment of inorganic phases (e.g., $\left.\mathrm{LiF}, \mathrm{Li}_{2} \mathrm{CO}_{3}, \mathrm{Li}_{2} \mathrm{O}\right) .{ }^{11}$ Liquid-phase products like ethylene glycol (EG) were later observed by pyrolysis coupled to gas chromatography-mass spectrometry (GC-MS) measurements, which can form from hydrolysis of semicarbonates in the presence of trace water. ${ }^{16}$

Many SEI-forming mechanisms also result in the release of gas-phase products, and hence their analysis has historically been one of the preferred techniques to probe SEI formation chemistry and cell-level degradation. ${ }^{16,19-33}$ Most of these studies have focused on quantification of bulk gas evolution after long-term cycling. From these single-point measurements in postcycled cells, the main gases identified to evolve in ECbased electrolytes on $\mathrm{Li}$ and graphite were $\mathrm{CO}_{2}, \mathrm{H}_{2}, \mathrm{CO}$, and $\mathrm{C}_{n<3}$ hydrocarbons, ${ }^{19,20}$ all of which have been shown to adversely affect cell performance. ${ }^{21}$ In general, $\mathrm{CO}_{2}$ is hypothesized to be released upon chemical SEI decomposition. ${ }^{22} \mathrm{H}_{2}$ has been suggested to result from direct reaction of $\mathrm{Li}$ with water, forming $\mathrm{LiOH}$ in the solid phase. ${ }^{23} \mathrm{CO}$ and hydrocarbons, however, are more conventionally described as originating from electrochemical solvent reduction, although the mechanisms for their formation are still debated. ${ }^{7} \mathrm{C}_{2} \mathrm{H}_{4}$ release, for instance, is associated with the single-electron reduction of $\mathrm{EC}$, resulting in the formation of LEDC in the solid phase. ${ }^{24}$ Finally, CO has been suggested to result from a two-electron reduction of EC, forming an alkoxy $\left({ }^{-} \mathrm{OCH}_{2} \mathrm{CH}_{2} \mathrm{O}^{-}\right)$that can bind to available $\mathrm{Li}^{+}{ }^{25}$ In contrast to postcycling measurements, operando MS experiments have also been employed in several Li-ion battery contexts previously. This has included analysis of electrochemical activation and decomposition at intercalation cathodes ${ }^{26-29}$ and study of $\mathrm{PF}_{6}^{-}$side reactions in $\mathrm{EC} / \mathrm{DMC} \mathrm{Li}_{2} \mathrm{MnO}_{3} /$ graphite cells, ${ }^{30}$ which has provided evidence of $\mathrm{CO}_{2}$ and $\mathrm{C}_{2} \mathrm{H}_{4}$ evolution at reducing potentials on graphite electrodes during the SEI formation cycle. ${ }^{22}$ However, online gas analysis has been less applied to study $\mathrm{Li}$ electrodes, especially in symmetric Li cells decoupled from possibly conflating effects of oxide cathodes.

The SEI chemistry, including relative proportions of phases, depends not only on electrolyte components such as salts and additives but also on the substrate, and thus the mechanism by which the SEI initially forms. ${ }^{34,35}$ On graphite, the SEI forms electrochemically upon first polarization of the electrode below approximately $1 \mathrm{~V}$ vs $\mathrm{Li}^{15}$ In EC-containing electrolytes, operando mass spectrometry and quartz crystal microbalance analyses during the SEI formation cycle, ${ }^{24}$ combined with $e x$ situ postcycling identification of $-\mathrm{OCO}_{2}$ groups in the resulting SEI through FTIR and XPS, ${ }^{18,35}$ have provided evidence that LEDC is the overwhelmingly dominant initial interphase species on graphite. ${ }^{24}$ LEDC can then chemically react with electrolyte components to form LMC and LEMC. ${ }^{15}$ On Li, unlike on graphite, an initial SEI forms by a chemical reaction as soon as the surface is exposed to electrolyte. The ensuing SEI repair under electrochemical conditions is largely assumed to be chemical in nature, resulting from exposure of freshly deposited $\mathrm{Li}$ to the electrolyte upon continuous SEI breakdown. ${ }^{3}$ Based on XPS and FTIR analyses of postcycled electrodes, as well as quantification of gases formed in the cell headspace, the resulting interphase formed on $\mathrm{Li}$ in the presence of carbonate electrolytes is likewise dominated by $\mathrm{OCO}_{2}$-containing species along with salt decomposition products (e.g., $\mathrm{LiF}$ ), with a lower amount of alkoxides compared to semicarbonates and inorganic species. ${ }^{12}$ This composition has been shown to depend on the presence of reactive salts such as $\mathrm{LiPF}_{6}$, as well as on the plating/stripping overpotential. $^{36}$ However, the specific mechanisms for the formation and evolution of the SEI on $\mathrm{Li}$ have not been precisely identified.

In this work, we study the dynamic process of SEI repair on $\mathrm{Li}$ electrodes using a custom-designed online gas chromatography cell, with the aim of elucidating the governing reaction pathways. The proportions of gas species detected within the cell, namely, $\mathrm{CO}_{2}, \mathrm{CO}, \mathrm{H}_{2}, \mathrm{CH}_{4}, \mathrm{C}_{2} \mathrm{H}_{4}$, and $\mathrm{C}_{2} \mathrm{H}_{2}$, vary sensitively under different cell chemistries and electrochemical conditions and, thus, serve as quantitative indicators of reaction branching. By studying the rate-dependent speciation of gases evolved, reactions that require an electron-transfer step are readily distinguished from those that are merely chemical in nature. Moreover, by observing specific molar ratios of evolved gases, we show that the dominant gas species- $\mathrm{CO}$, $\mathrm{CH}_{4}$, and $\mathrm{C}_{2} \mathrm{H}_{4}$-imply the direct and quantitative electrochemical production of LEMC, LEDC, and lithiated alkoxides. The effects of electrolyte salt and solvent fluorination are also investigated, among which certain gas evolution signatures are shown to link directly to superior Coulombic efficiency.

\section{METHODS}

Materials Preparation. Electrochemical cells were prepared and assembled inside an argon-filled glovebox $\left(<0.1 \mathrm{ppm}\right.$ of $\mathrm{H}_{2} \mathrm{O},<0.1$ ppm of $\mathrm{O}_{2}, \mathrm{MBraun}$ ). Cell hardware was cleaned with ethanol and deionized (DI) water $(18.2 \mathrm{M} \Omega \mathrm{cm})$ and then dried in a vacuum oven at $80{ }^{\circ} \mathrm{C}$ for at least $8 \mathrm{~h}$ before being brought inside the glovebox. Stainless steel disk meshes (McMaster Carr, U.S.A.) were washed with ethanol and DI water, dried overnight at $120{ }^{\circ} \mathrm{C}$ in a Buchi vacuum glass oven, and transferred to the glovebox without ambient exposure. Separators were punched from Whatman paper filters and likewise dried overnight in a vacuum glass oven at $120{ }^{\circ} \mathrm{C}$. Copper electrodes were punched from copper foil (0.003 in. thick, Lyon Industries) outside of the glovebox, washed with ethanol and DI water, dried overnight at $120^{\circ} \mathrm{C}$ under vacuum in a glass oven, and brought inside the glovebox without atmospheric exposure. Aluminum foils coated with $\mathrm{LiFePO}_{4}(91 \%$ active material, $120 \mathrm{~g} /$ $\mathrm{m}^{2}$ active material) were purchased from MTI Corporation and punched to $\varnothing 5 / 8$-in disks inside the glovebox to be used as electrodes. Lithium metal strips (0.75 mm thick, Alfa Aesar) were rolled and punched to their appropriate diameter inside the glovebox immediately before use. Battery-grade lithium hexafluorophosphate $\left(\mathrm{LiPF}_{6}\right)$ in ethylene carbonate/dimethyl carbonate (EC/DMC) 1:1 vol \% and in ethylene carbonate/diethyl carbonate (EC/DEC) 1:1 vol $\%$ and neat dimethyl carbonate (DMC, 99+\%, anhydrous) were purchased from Millipore Sigma. Ethylene carbonate (EC, 99+\%) was purchased from Acros Organics. 4-Fluoro-1,3-dioxolan-2-one (fluoroethylene carbonate, FEC, 98\%) was purchased from Alfa Aesar. Salts were purchased either from Millipore Sigma $\left(\mathrm{LiPF}_{6}, \mathrm{LiClO}_{4}\right)$ or from Alfa Aesar (LiTFSI) and were dried overnight at $120^{\circ} \mathrm{C}$ in a vacuum glass oven before being brought inside the glovebox without atmospheric exposure. All electrolytes and solvent mixtures (EC/ DMC, 1:1 vol \%) were further purified for at least $12 \mathrm{~h}$ (typically, several days) inside the glovebox by adding fresh $4 \AA$ molecular sieves (Millipore Sigma) after preparation, which had been previously dried in a vacuum glass oven at $250{ }^{\circ} \mathrm{C}$. Using Karl Fischer titration, the water content of all dried solvents from which $\mathrm{LiClO}_{4}$ and LiTFSIcontaining electrolytes were prepared was determined to be less than 
$1 \mathrm{ppm}\left(\mathrm{LiPF}_{6}\right.$-containing electrolytes do not accumulate water due to salt hydrolysis, as discussed further below).

Cell Preparation. Cells used for online gas measurements were assembled with symmetric $15 \mathrm{~mm} \mathrm{Li}$ metal electrodes, a $20 \mathrm{~mm}$ Whatman paper filter separator soaked in $250 \mu \mathrm{L}$ of electrolyte ( $1 \mathrm{M}$ $\mathrm{LiPF}_{6}$ or $1 \mathrm{M} \mathrm{LiClO}_{4}$ in EC/DMC 1:1 vol \%, $\left.1 \mathrm{M} \mathrm{LiPF}_{6}\right)$, and a Ø0.75-in. 316 stainless steel mesh as the current collector (Figure S1). Swagelok cells used for Coulombic efficiency measurements were assembled using a $12 \mathrm{~mm} \mathrm{Li}$ metal electrode, a $12 \mathrm{~mm}$ Whatman paper filter separator soaked in $150 \mu \mathrm{L}$ of electrolyte, a $12 \mathrm{~mm}$ copper disk as the positive electrode, and a Ø0.5-in. 316 stainless steel mesh as the current collector.

Electrochemical Measurements. All electrochemical measurements were conducted using BioLogic MPG-2 and VSP potentiostats. After assembly, all gas analysis cells were rested under constant argon flow for at least $2 \mathrm{~h}$ before electrochemical measurements. Half-cycle pulse experiments were conducted galvanostatically at $0.5 \mathrm{~mA} / \mathrm{cm}_{\mathrm{Li}}^{2}$ to varying capacities. Current density variation experiments were conducted to full capacity before failure (i.e., short-circuit), which was visually assessed as occurring when a steep drop in potential to $\sim 0 \mathrm{~V}$ was observed in potential vs time curves. Cycling of $\mathrm{Lill} L \mathrm{LiFePO}{ }_{4}$ cells, used to identify anodic or cathodic gas evolution from $\mathrm{Li}$, was conducted at $0.5 \mathrm{~mA} / \mathrm{cm}^{2}$ between 2.5 and $4 \mathrm{~V}$ with a constant current-constant voltage $(\mathrm{CC}-\mathrm{CV})$ protocol (beginning on charge) to a minimum current density of $25 \mu \mathrm{A} / \mathrm{cm}_{\mathrm{Li}}^{2}$ with a $3 \mathrm{~h}$ open circuit resting period between each half-cycle (measured maximum capacity of $\sim 2 \mathrm{mAh} / \mathrm{cm}^{2}$ or $\sim 165 \mathrm{mAh} / \mathrm{g}$ ). Cycling of baseline, symmetric $\mathrm{LiFePO}_{4} \| \mathrm{LiFePO}$ cells was conducted at $0.5 \mathrm{~mA} / \mathrm{cm}^{2}$ Li to capacities of $0.5 \mathrm{mAh} / \mathrm{cm}^{2}$ in each half cycle. Prior to assembly in the symmetric cell, $\mathrm{LiFePO}_{4}$ electrodes were charged to capacities of $1 \mathrm{mAh} / \mathrm{cm}^{2}$ (83 $\mathrm{mAh} / \mathrm{g}_{\text {active, }}, 50 \%$ capacity $)$ and $1.5 \mathrm{mAh} / \mathrm{cm}^{2}\left(125 \mathrm{mAh} / \mathrm{g}_{\text {active, }}, 75 \%\right.$ capacity) in a $\mathrm{Lill} \mathrm{LiFePO}_{4}$ half-cell and then used as positive and negative electrodes, respectively. Coulombic efficiency measurements were conducted in a CullLi Swagelok cell at $0.5 \mathrm{~mA} / \mathrm{cm}_{\mathrm{Li}}^{2}$ to a capacity of $1 \mathrm{mAh} / \mathrm{cm}^{2}$ and a stripping potential cutoff of $2 \mathrm{~V}$ with a 5 min rest period between each half-cycle. The Coulombic efficiency was then computed as the ratio of the charge transferred between the stripping and the plating half-cycles on copper, i.e., $Q_{\text {stripped }} / Q_{\text {plated }}$.

Online Gas Measurements. Online gas measurements utilized a custom-built, two-electrode electrochemical cell through which argon flowed at $5 \mathrm{mg} / \mathrm{min}$. The gases evolved during rest (postassembly) and during active plating/stripping were both captured from the cell headspace $(\sim 6 \mathrm{~mL})$ for analysis. The gas mixture flowed continuously to an Agilent $7890 \mathrm{~B}$ gas chromatograph (GC) fitted with flame ionization (FID) and thermal conductivity (TCD) detectors (Figure 1a). The columns and detectors were capable of discerning among $\mathrm{CO}_{2}(<1 \mathrm{ppm}), \mathrm{CO}(<1 \mathrm{ppm}), \mathrm{H}_{2}(<10 \mathrm{ppm}), \mathrm{Ar}$ (<1 ppm), $\mathrm{CH}_{4}$ $(<1 \mathrm{ppm}), \mathrm{C}_{2} \mathrm{H}_{6}(<1 \mathrm{ppm}), \mathrm{C}_{2} \mathrm{H}_{4}(<1 \mathrm{ppm})$, and $\mathrm{C}_{2} \mathrm{H}_{2}(<1 \mathrm{ppm})$. The flow was sampled by the GC every $15 \mathrm{~min}$, and excess gas was disposed. The elution curves (examples of which are shown in Figure S2) were numerically processed, and the peaks were detected and integrated using a custom numerical code which were then compared to those from elution curves of gas calibration standards $\left(1 \% \mathrm{CO}_{2}\right.$, $\mathrm{CO}, \mathrm{H}_{2} ; 15$ ppm of $\mathrm{CH}_{4}, \mathrm{C}_{2} \mathrm{H}_{6}, \mathrm{C}_{2} \mathrm{H}_{4}, \mathrm{C}_{2} \mathrm{H}_{2}$; Supelco, U.S.A.), from which the concentrations of each species in the flow stream were calculated. The molar flow rates of each species were then computed using the ideal gas law. All experiments were conducted at room temperature and pressure. Immediately following cell assembly and prior to each gas measurement, each cell was purged with clean argon (99.9997\%, Airgas) for 5-15 $\mathrm{min}$ at $100 \mathrm{mg} / \mathrm{min}$ to remove any gas dissolved in the electrolyte. After purging, the flow rate was lowered to $5 \mathrm{mg} / \mathrm{min}$. Cells were then rested for $2 \mathrm{~h}$ while acquiring both gas evolution and open circuit voltage (OCV) data, resulting in at least 8 gas evolution data points at OCV. The last three gas evolution data points immediately before starting any electrochemical activity were averaged and used to establish the baseline for each. Additional details on the molar flow rate and baseline calculations can be found in the Supporting Information. Water contamination from the Ar stream was estimated to be $11 \mathrm{ppm}$ (see Supporting Information, Figure S3). To certify that online gas evolution measurements were reproducible,
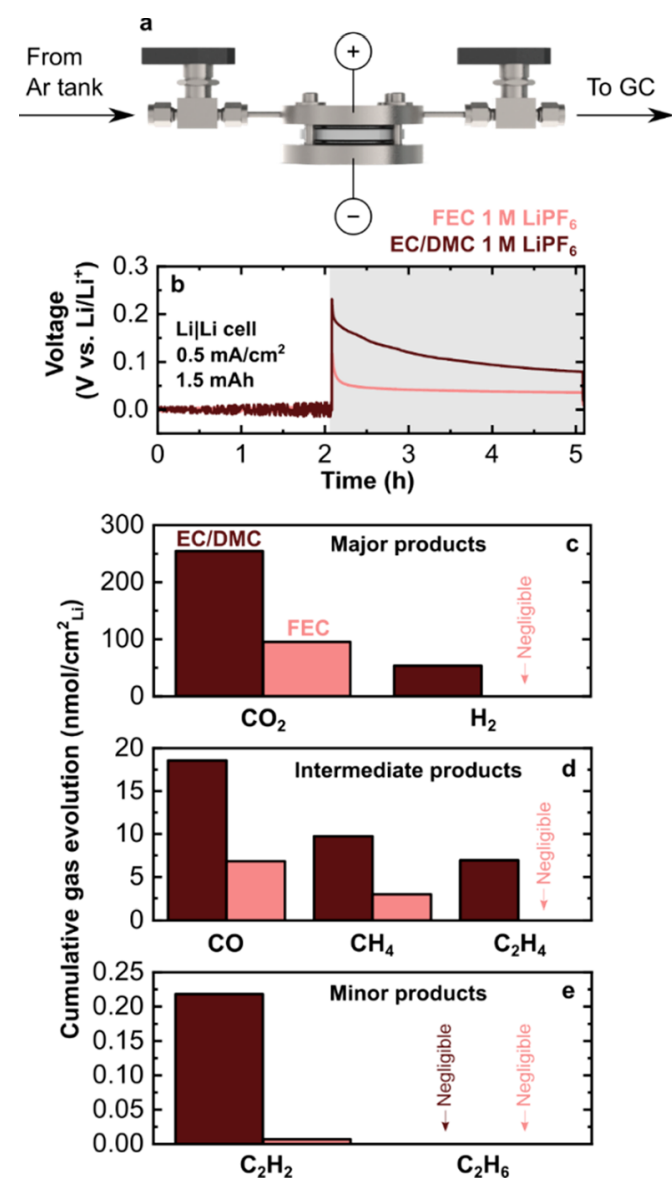

Figure 1. (a) Custom-built electrochemical cell for gas headspace sampling. (b) Potential vs time for the galvanostatic discharge of a Lill $\mathrm{Li}$ cell with $1 \mathrm{M} \mathrm{LiPF}_{6}$ in EC/DMC or FEC at $0.5 \mathrm{~mA} / \mathrm{cm}_{\mathrm{Li}}^{2}$ for $3 \mathrm{~h}$. Gray background indicates onset of applied current following the rest step. (c-e) Baseline-corrected, cumulative (c) major, (d) intermediate, and (e) minor gas products evolved over the totality of plating/stripping.

three symmetric Lill Li gas cells were assembled with $1 \mathrm{M} \mathrm{LiPF}_{6}$ in $\mathrm{EC} / \mathrm{DMC}$ and were galvanostatically polarized at $0.5 \mathrm{~mA} / \mathrm{cm}_{\mathrm{Li}}^{2}$ to a capacity of $1.5 \mathrm{mAh} / \mathrm{cm}_{\mathrm{Li}}^{2}$ after $2 \mathrm{~h}$ of resting. The major gases evolved show excellent quantitative and qualitative agreement (Figure S4).

\section{RESULTS}

Gas Evolution in EC/DMC. Gas evolution rates were measured periodically every $15 \mathrm{~min}$ in symmetric LillLi cells (Figure 1a). We first discuss all results obtained in EC/DMC and later return to compare illustrative differences in a fluorinated solvent, FEC, which are plotted alongside for ease of comparison. Figure $1 \mathrm{~b}$ shows a typical measurement in which the cell was rested postassembly for $2 \mathrm{~h}$ at OCV, followed by a first galvanostatic half-cycle (one Li electrode subjected to charge/stripping and one to discharge/plating) at $0.5 \mathrm{~mA} / \mathrm{cm}_{\mathrm{Li}}^{2}$ to a capacity of $1.5 \mathrm{mAh} / \mathrm{cm}_{\mathrm{Li}}^{2}$. First, the total quantities of each gas evolved over this period were analyzed by integrating their rate of evolution over the half-cycle. Such integration yields results that are analogous to prior singlepoint measurements in literature that investigated SEI chemistry at the conclusion of cycling. ${ }^{19,20,33,37,38}$ Using this technique, $\mathrm{CO}_{2}, \mathrm{H}_{2}, \mathrm{CO}, \mathrm{CH}_{4}, \mathrm{C}_{2} \mathrm{H}_{4}$, and $\mathrm{C}_{2} \mathrm{H}_{2}$ were identified as gas-phase products. As shown in Figure 1c, the major gas evolved in EC/DMC was $\mathrm{CO}_{2}$ at $255 \mathrm{nmol} / \mathrm{cm}_{\mathrm{Li}}^{2}$ (all 
quantities herein are normalized to the geometric surface area of $\mathrm{Li})$, followed by $\mathrm{H}_{2}\left(54 \mathrm{nmol} / \mathrm{cm}_{\mathrm{Li}}^{2}\right), \mathrm{CO}\left(19 \mathrm{nmol} / \mathrm{cm}_{\mathrm{Li}}^{2}\right)$, $\mathrm{CH}_{4}\left(9.7 \mathrm{nmol} / \mathrm{cm}_{\mathrm{Li}}^{2}\right), \mathrm{C}_{2} \mathrm{H}_{4}\left(6.9 \mathrm{nmol} / \mathrm{cm}_{\mathrm{Li}}^{2}\right)$, and $\mathrm{C}_{2} \mathrm{H}_{2}$ $\left(0.22 \mathrm{nmol} / \mathrm{cm}^{2}{ }_{\mathrm{Li}}\right)$. High quantities of $\mathrm{CO}_{2}$ in $\mathrm{EC} / \mathrm{DMC}$ have been reported previously in postcycled cells with $\mathrm{Li}$ anodes, ${ }^{19}$ and its evolution was largely attributed to aging of the SEI, for instance, by electrochemical reduction of semicarbonates (i.e., $\mathrm{ROCO}_{2} \mathrm{Li}$, where $\mathrm{R}=\mathrm{CH}_{2} \mathrm{CH}_{2} \mathrm{OCO}_{2} \mathrm{Li}, \mathrm{CH}_{2} \mathrm{CH}_{2} \mathrm{OH}$, or $\left.\mathrm{CH}_{3}\right)^{24}$ or sustained chemical reactions between the SEI and protonated electrolyte contaminants such as $\mathrm{HF}$ and $\mathrm{H}_{2} \mathrm{O}$. ${ }^{4,16,39} \mathrm{H}_{2}$ evolution, on the other hand, was previously attributed to reduction of $\mathrm{Li}^{+}$in the presence of $\mathrm{HF}$, i.e., $\mathrm{Li}^{+}+$ $\mathrm{e}^{-}+\mathrm{HF} \rightarrow \mathrm{LiF}+(1 / 2) \mathrm{H}_{2},{ }^{40}$ where $\mathrm{HF}$ arises from hydrolysis of $\mathrm{PF}_{6}{ }^{-}$by trace amounts of water; or from the direct reaction of $\mathrm{Li}$ with trace water, i.e., $2 \mathrm{Li}+2 \mathrm{H}_{2} \mathrm{O} \rightarrow 2 \mathrm{LiOH}+\mathrm{H}_{2}$. Our observations of $\mathrm{C}_{2} \mathrm{H}_{4}, \mathrm{CH}_{4}$, and $\mathrm{CO}$ are consistent with previous postcycling measurements in EC-containing solvents on both $\mathrm{Li}^{4,16}$ and graphite. ${ }^{4,19,24}$ In particular, observation of $\mathrm{C}_{2} \mathrm{H}_{4}$, a signature of EC decomposition, during SEI formation on graphite has provided central evidence that EC is preferentially reduced when present in formulations with other alkyl carbonates (e.g., DEC or DMC). ${ }^{24}$ As far as we know, formation of $\mathrm{C}_{2} \mathrm{H}_{2}$ has not been reported previously. Note that $\mathrm{C}_{2} \mathrm{H}_{6}$, a plausible unique decomposition product of $\mathrm{DMC}^{24}$ has been previously observed in minor quantities in cycled cells with graphite anodes ${ }^{19}$ but was not observed here. Thus, our results support the fact that EC decomposition is favored over DMC on Li.

In contrast to cumulative gas evolution integrated over the entire electrochemically active period, Figure 2 shows online measurements for comparable LillLi cells in which the rate of each gas's evolution was measured throughout the testing

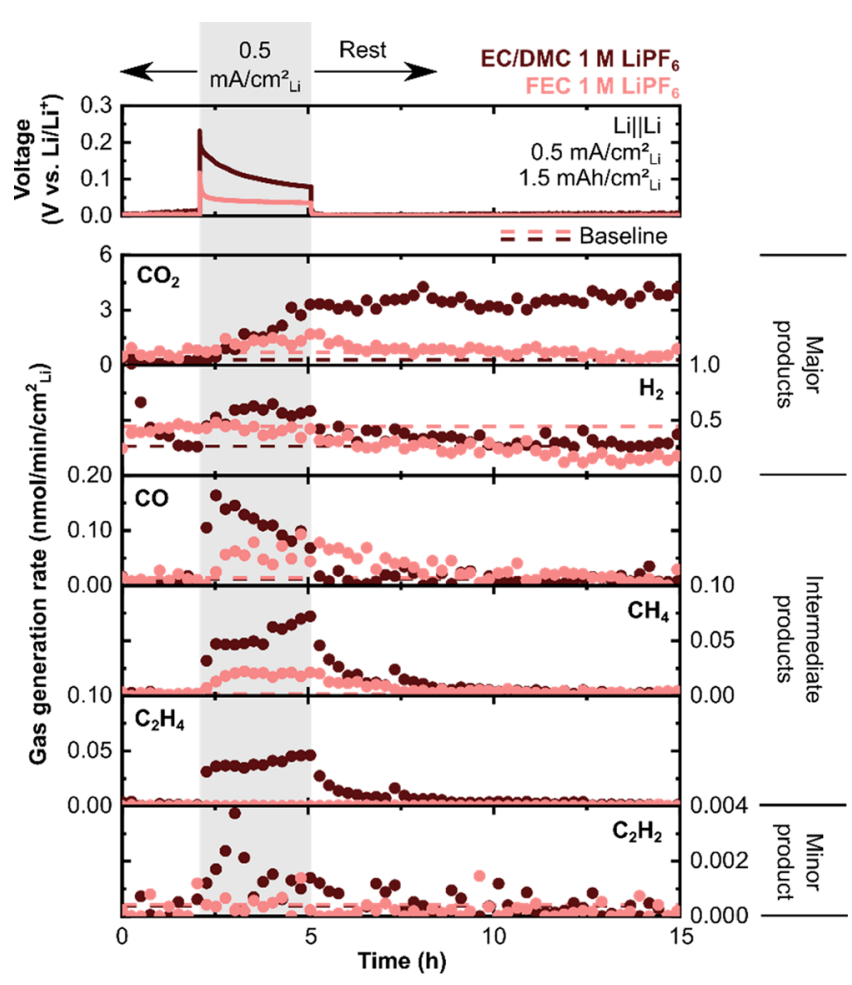

Figure 2. Time-dependent online gas evolution curves for a symmetric $\mathrm{LillLi}$ cell with $1 \mathrm{M} \mathrm{LiPF}_{6}$ in EC/DMC and FEC electrolytes at $0.5 \mathrm{~mA} / \mathrm{cm}^{2}$ i. period at $15 \mathrm{~min}$ intervals. During the online measurements in EC/DMC, as expected, the same characteristic gases were detected-namely, $\mathrm{CO}_{2}, \mathrm{H}_{2}, \mathrm{CO}, \mathrm{CH}_{4}, \mathrm{C}_{2} \mathrm{H}_{4}$, and $\mathrm{C}_{2} \mathrm{H}_{2}$-as in the cumulative measurement. However, the dynamic nature of the measurements revealed new insights that could not be captured by a single postcycle measurement. For example, a sharp and clear increase in evolution rate of all gases was observed as soon as the current began to flow, indicating direct coupling with active Li plating/stripping. After the cells were relaxed to $\mathrm{OCV}$, the gas evolution rates of nearly all species ( $\left.\mathrm{CO}, \mathrm{H}_{2}, \mathrm{CH}_{4}, \mathrm{C}_{2} \mathrm{H}_{4}, \mathrm{C}_{2} \mathrm{H}_{2}\right)$ returned to the baseline. The same behavior was even more clearly illustrated when multiple consecutive galvanostatic pulses, separated by rest steps, were applied to the cell (Figure S5). However, a clear exception was observed for $\mathrm{CO}_{2}$ : its evolution continued at a near-constant rate for the rest of the measurement and never returned to the baseline. Together, these results indicate that $\mathrm{H}_{2}, \mathrm{CO}, \mathrm{CH}_{4}$, $\mathrm{C}_{2} \mathrm{H}_{4}$, and $\mathrm{C}_{2} \mathrm{H}_{2}$ all form during active cycling of $\mathrm{Li}$; in contrast, $\mathrm{CO}_{2}$ does not require active $\mathrm{Li}$ cycling to evolve. The persistence of $\mathrm{CO}_{2}$ evolution for more than $10 \mathrm{~h}$ with a nearly constant rate $\left(\sim 3.7 \mathrm{nmol} / \mathrm{min} / \mathrm{cm}_{\mathrm{Li}}^{2}\right)$ after returning to $\mathrm{OCV}$ indicates that $\mathrm{CO}_{2}$ formation, though initiated somehow by active current flow within the cell, evolves by a chemical process thereafter, e.g., by aging of a metastable SEI. While the formation of $\mathrm{CO}_{2}$ is not surprising due to existing hypotheses that $\mathrm{CO}_{2}$ is released from chemical SEI decomposition, 7,11,39 this measurement provides direct evidence confirming that a $\mathrm{Li}$ SEI continues to release $\mathrm{CO}_{2}$ even in the lack of electrochemical activity and over long time scales (at least $10 \mathrm{~h}$ ) after relaxation of the current. So far, chemical degradation of the SEI resulting in $\mathrm{CO}_{2}$ release had been hypothesized or extrapolated from ex situ analyses of postcycled cells. ${ }^{11} \mathrm{We}$ note that the long tails $(\sim 1 \mathrm{~h})$ corresponding to relaxation of gas evolution upon the cell's return to OCV (most evident in $\mathrm{CH}_{4}$ and $\mathrm{C}_{2} \mathrm{H}_{4}$ traces) can be attributed to excess gas dissolved in the electrolyte, which is slowly liberated to the headspace for a finite time once the applied current is removed. Similarly, at least part of the delay in detection of $\mathrm{CO}_{2}$ evolution after galvanostatic polarization can be attributed to the high solubility of $\mathrm{CO}_{2}$ in the electrolyte, which we measured ${ }^{41}$ to be $143.3 \mathrm{mM}$ in EC/DMC (Table S1, $1 \mathrm{M} \mathrm{LiPF}_{6}$ ), resulting in a maximum of $36 \mu \mathrm{mol}$ of $\mathrm{CO}_{2}$ dissolved in the $250 \mu \mathrm{L}$ of $1 \mathrm{M}$ $\mathrm{LiPF}_{6}$ in $\mathrm{EC} / \mathrm{DMC}$. Additionally, it is important to note that our gas evolution experiments displayed good agreement across different cells (Figure S4).

For measurements conducted in symmetric LillLi cells, it is not possible to pinpoint the electrode at which the gases evolved, i.e., whether predominantly from anodic $\mathrm{Li}$, cathodic $\mathrm{Li}$, or both. To investigate this point further, $\mathrm{LilliFePO}_{4}$ halfcells were assembled. Background measurements of a symmetric $\mathrm{LiFePO}_{4} \| \mathrm{LiFePO}_{4}$ cell first indicated that negligible gases were evolved over representative charging and discharging conditions (Figure S6), and, thus, $\mathrm{LiFePO}_{4}$ counter electrodes can allow for contributions of a single $\mathrm{Li}$ electrode to be isolated. Interestingly, in $\mathrm{LilliFePO}_{4}$ cells, gas evolution was only observed during the first charge (Figure 3), in which $\mathrm{Li}^{+}$deintercalated from $\mathrm{LiFePO}_{4}$ and was plated on $\mathrm{Li}$ metal. Specifically, the gases evolved on plating were $\mathrm{CO}_{2}, \mathrm{H}_{2}$, $\mathrm{CO}, \mathrm{CH}_{4}, \mathrm{C}_{2} \mathrm{H}_{4}$, and $\mathrm{C}_{2} \mathrm{H}_{2}\left(\sim 1-2 \mathrm{nmol} / \mathrm{min} / \mathrm{cm}_{\mathrm{Li}}^{2}\right.$ of $\mathrm{CO}_{2}$; $\sim 0.3 \mathrm{nmol} / \mathrm{min} / \mathrm{cm}^{2}{ }_{\mathrm{Li}}$ of $\mathrm{H}_{2} ; \sim 0.4 \mathrm{nmol} / \mathrm{min} / \mathrm{cm}^{2}{ }_{\mathrm{Li}}$ of $\mathrm{CO}$; $\sim 0.1 \mathrm{nmol} / \mathrm{min} / \mathrm{cm}^{2}{ }_{\mathrm{Li}}$ of $\mathrm{CH}_{4}$ and $\mathrm{C}_{2} \mathrm{H}_{4}$ in nearly equal amounts; $\sim 0.05 \mathrm{nmol} / \mathrm{min} / \mathrm{cm}^{2}{ }_{\mathrm{Li}}$ of $\mathrm{C}_{2} \mathrm{H}_{2}$ ). These amounts are quantitatively consistent with multiple experiments in $\mathrm{Lill} \mathrm{Li}$ 

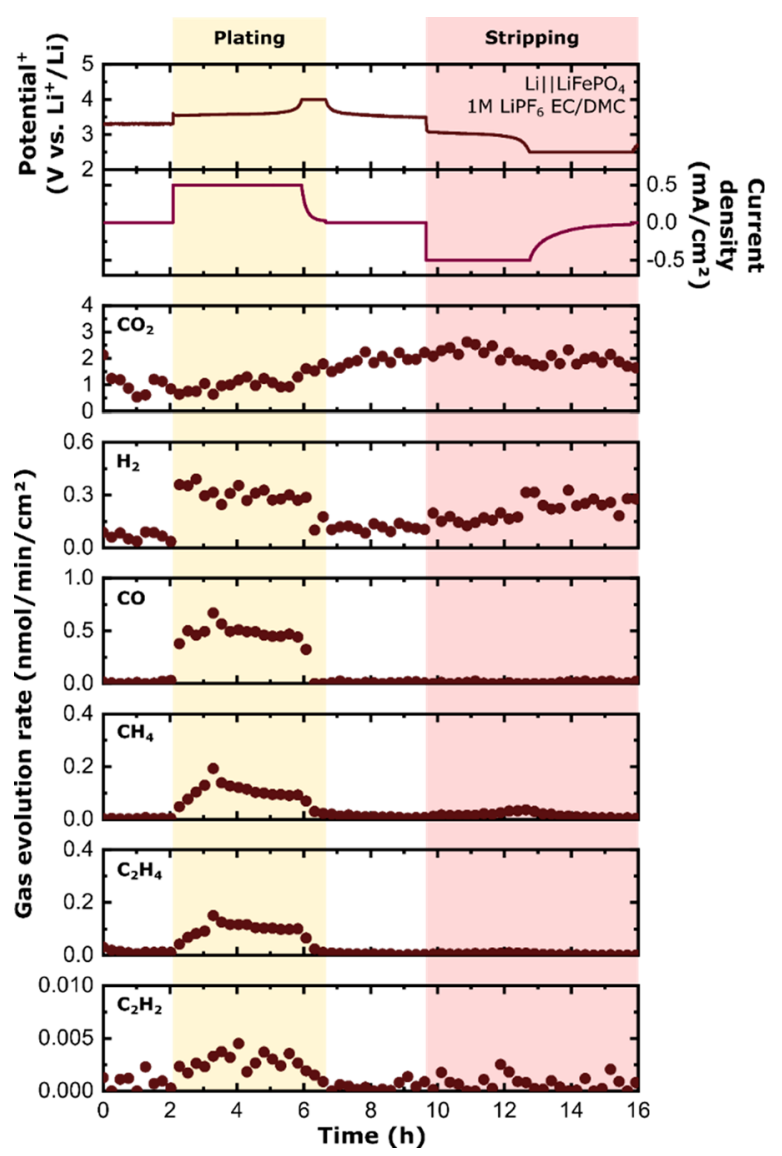

Figure 3. Gas evolution in the first charge/discharge cycle in a Lill $\mathrm{LiFePO}_{4}$ half-cell with $1 \mathrm{M} \mathrm{LiPF}_{6}$ in EC/DMC. Cycled using a constant current-constant voltage $(\mathrm{CC}-\mathrm{CV})$ protocol at $0.5 \mathrm{~mA} /$ $\mathrm{cm}^{2}$ between 2.5 and $4 \mathrm{~V}$.

cells at the same current densities (Figure S4). The subsequent discharge, corresponding to $\mathrm{Li}$ oxidation at the anode and $\mathrm{Li}^{+}$ intercalation into $\mathrm{LiFePO}_{4}$, meanwhile exhibited negligible gas evolution. Similar to the previous experiments, activation of $\mathrm{CO}_{2}$ evolution was again observed during the first charge ( $\mathrm{Li}$ plating), after which its evolution rate remained relatively constant (at $2-3 \mathrm{nmol} / \mathrm{min} / \mathrm{cm}_{\mathrm{Li}}^{2}$ ), even during the subsequent discharge ( $\mathrm{Li}$ stripping). Thus, the evolved gases in Figures 1 and 2 arise almost entirely from the $\mathrm{Li}$ which is being plated, rather than the Li being stripped.

Rate-Dependent Gas Evolution in EC/DMC. We next looked more closely at whether, and how, the $\mathrm{Li}$ plating current density influences the proportions and rates of the gases evolved. In rate-dependent measurements, rather than plate to a fixed capacity as before, a single galvanostatic current step was applied until failure occurred due to short-circuiting, assumed to occur due to dendrite puncture of the separator. This condition was chosen to allow cells to reach maximum capacity before failure, maximizing the number of data points collected during the stable electrochemical regime. The resulting capacities ranged from $0.5-4 \mathrm{mAh} / \mathrm{cm}^{2}$ depending on the current density. Galvanostatic data for all cells along with their total capacities attained at point-of-failure are shown in Figure S7, and representative galvanostatic data for each condition are summarized in Figure 4a,b. While inevitable cellto-cell variability was observed in the time-to-short-circuit given the stochastic nature of the measurement, good reproducibility was observed for gas identities and relative proportions across multiple cells for each condition.

The mean formation rate of each gas species at each current density, determined by averaging over the entirety of the single-pulse step, is summarized in Figure 4c. Note that, during active stripping/plating, the gas evolution rates were reasonably constant in time with few outliers, supporting the use of the mean current as a representative parameter across different current densities and electrolytes. However, scatter tended to increase as current densities increased. Hence, large error bars at high current densities $\left(4 \mathrm{~mA} / \mathrm{cm}^{2}{ }_{\text {Li }}\right)$ can be attributed to increased data scattering as well as to the smaller number of gas evolution points resulting from the shorter plating time span (e.g., see Figure $4 \mathrm{a}, \mathrm{b}$ and Figure S7a,b). In $\mathrm{EC} / \mathrm{DMC}, \mathrm{CO}_{2}$ and $\mathrm{H}_{2}$ exhibited rates of formation that were insensitive to the current density: averaged evolution rates remained roughly constant at $\sim 0.7$ and $\sim 0.1 \mathrm{nmol} / \mathrm{min} / \mathrm{cm}^{2} \mathrm{Li}$, respectively, over $0.5-4 \mathrm{~mA} / \mathrm{cm}^{2}$. We hereafter refer to these species as "chemically evolved" given their rate-independence (discussed further below). The evolution of all other compounds (namely, $\mathrm{CH}_{4}, \mathrm{C}_{2} \mathrm{H}_{2}$, and $\mathrm{C}_{2} \mathrm{H}_{4}$ ), however, showed an unexpectedly strong and linear dependence on the applied current. CO formation was also observed to increase with current density, but our measurement uncertainty does not allow us to confirm that this dependence is equally linear.

The linear dependence of gas evolution rates with current density can be explained by two possibilities: (1) Higher current densities lead to more inhomogeneous plating and hence greater rates of surface area increase, facilitating the chemical reaction between freshly plated $\mathrm{Li}$ and the electrolyte, or (2) the reaction evolving these gases relies on electrons transferred through the interface, i.e., solvent reduction occurs not through a chemical reaction of elemental $\mathrm{Li}$ with the electrolyte, but rather an electrochemical step induced by an electron transfer. We rule out the first hypothesis as unlikely because it is improbable that the complex interplay between a changing surface area and ensuing $\mathrm{Li}-$ electrolyte reactions would result in an ordered and strongly linear relationship with current density. Therefore, unlike the initial formation of the SEI during resting at OCV, which is chemical in nature, the current dependence of the dynamic SEI repair suggests that solvent reduction scales with the rate of electron flux through the interface; hence hereafter, we describe these gases as "electrochemically evolved". In EC/DMC, these are $\mathrm{CH}_{4}$, $\mathrm{C}_{2} \mathrm{H}_{4}, \mathrm{C}_{2} \mathrm{H}_{2}$, and CO.

A striking observation from these measurements in $\mathrm{EC} /$ DMC is that $\mathrm{CO}$ and $\mathrm{CH}_{4}$, both of which form at rates that increase proportionally with current density, are evolved at approximately the same ratio of $2 \mathrm{~mol}$ of $\mathrm{CO}$ per $1 \mathrm{~mol}$ of $\mathrm{CH}_{4}$ regardless of the current density, as shown in Figure 5a. The ratio of $\mathrm{C}_{2} \mathrm{H}_{4}$ to $\mathrm{CH}_{4}$ evolution also displays a 1:1 dependency at polarizations of $1 \mathrm{~mA} / \mathrm{cm}^{2}$ or lower (Figure $5 \mathrm{~b}$ ), shifting toward higher ratios (up to $\sim 2.5$ ) at higher current densities, indicating increased selectivity toward $\mathrm{C}_{2} \mathrm{H}_{4}$. In contrast, $\mathrm{C}_{2} \mathrm{H}_{2}$, formed in trace amounts, was not strongly favored at any particular current density, as evidenced by the low $\mathrm{C}_{2} \mathrm{H}_{2} / \mathrm{CH}_{4}$ molar ratio $(\sim 0.04-0.08$, Figure $5 \mathrm{c})$. These ratios of $\mathrm{CO}$ or $\mathrm{C}_{2} \mathrm{H}_{4}$ with respect to $\mathrm{CH}_{4}$, in particular, provide important clues into the electrolyte reaction pathways occurring under different conditions, which we discuss in greater detail later.

Evolution Mechanisms of Chemically Formed Species $\left(\mathrm{CO}_{2}\right.$ and $\left.\mathrm{H}_{2}\right) \cdot \mathrm{CO}_{2}$ evolution from an SEI, especially in the 

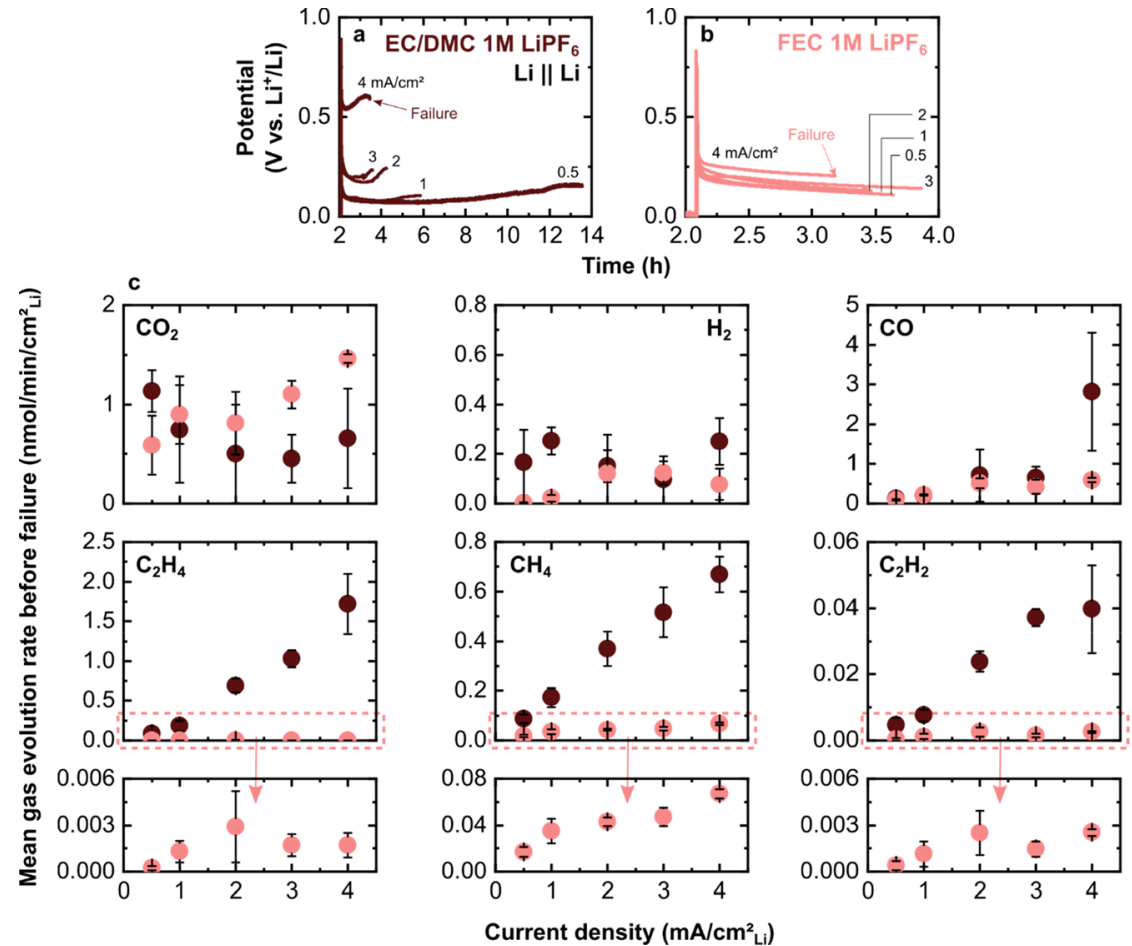

Figure 4. Mean gas evolution rate dependence on current density. Representative galvanostatic curves for symmetric LillLi cells with varying current densities with $1 \mathrm{M} \mathrm{LiPF}_{6}$ in (a) EC/DMC or (b) FEC. (c) Baseline-corrected mean gas evolution rate averaged over the entire stable plating/stripping period.
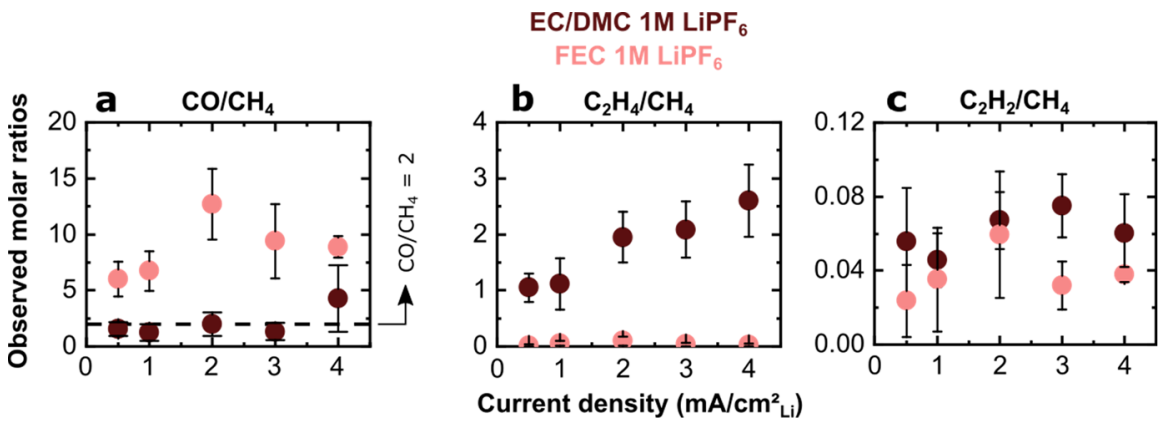

Figure 5. $(\mathrm{a}-\mathrm{c})$ Observed molar ratios of electrochemically evolved gas species with respect to $\mathrm{CH}_{4}$ as a function of current density, $(\mathrm{a}) \mathrm{CO} / \mathrm{CH}_{4}$, (b) $\mathrm{C}_{2} \mathrm{H}_{4} / \mathrm{CH}_{4}$, and (c) $\mathrm{C}_{2} \mathrm{H}_{2} / \mathrm{CH}_{4}$.

absence of applied current, can theoretically arise from sustained SEI reactivity that is either self-driven due to intrinsic metastability of specific phases (e.g., $\mathrm{ROCO}_{2} \mathrm{Li} \rightarrow$ $\mathrm{CO}_{2}+\mathrm{ROLi}$, the formation mechanisms of which will be discussed in the forthcoming section) or which, alternatively, is driven by reaction with electrolyte species. For the latter, SEI attacks by protic contaminants (e.g., $2 \mathrm{ROCO}_{2} \mathrm{Li}+\mathrm{H}_{2} \mathrm{O} \rightarrow$ $\left.\mathrm{Li}_{2} \mathrm{CO}_{3}+\mathrm{CO}_{2}+2 \mathrm{ROH}\right)$ or by reactive salts are both hypothetically possible (Figure S8). To identify whether selfdriven or electrolyte-induced mechanisms are responsible for the large $\mathrm{CO}_{2}$ evolution observed herein, a symmetric $\mathrm{Li}$ cell was cycled to $1.5 \mathrm{mAh} / \mathrm{cm}^{2}{ }_{\mathrm{Li}}$ to form an initial SEI akin to that formed under previous electrochemical conditions. After this formation step, the cell was disassembled, both Li electrodes were rinsed thoroughly with DME to remove trace electrolyte, and then the cell was reassembled in a clean cell with a dry separator to enable resumption of gas measurements without electrolyte present. $\mathrm{CO}_{2}$ evolution ceased during the ensuing rest time of $5 \mathrm{~h}$. However, after reassembling the same electrodes with preformed SEI again with electrolyte (1 M $\mathrm{LiPF}_{6}$ in EC/DEC), $\mathrm{CO}_{2}$ evolution resumed to nearly the same levels as in the initial cell. This reveals that that $\mathrm{CO}_{2}$ evolution is strongly driven by the electrolyte (Figure S9; note that DEC was used in place of DMC for technical reasons here but is not expected to alter the conclusions, as EC/DEC is, like $\mathrm{EC} / \mathrm{DMC}$, also expected to decompose toward $\mathrm{ROCO}_{2} \mathrm{Li}$ species. These can then react with the electrolyte to release $\mathrm{CO}_{2}$; see Supporting Information for more details). To investigate the electrolyte-derived origin of $\mathrm{CO}_{2}$ evolution further-whether from solvent or salt-similar single-pulse measurements were conducted with either $1 \mathrm{M} \mathrm{LiClO}_{4}$ or $1 \mathrm{M}$ LiTFSI in EC/DMC, rather than $\mathrm{LiPF}_{6}$. Strikingly, no $\mathrm{CO}_{2}$ evolution was observed above an initial resting baseline (Figures S10). Hence, we ascribe the dominant mechanism of $\mathrm{CO}_{2}$ evolution observed in EC/DMC electrolyte to one of $\mathrm{PF}_{6}{ }^{-}$(or derived HF) reaction with the SEI (Figure S8 and Table S2) rather than $\mathrm{H}_{2} \mathrm{O}$, which is approximately equally present due to trace contamination in all three electrolytes. 


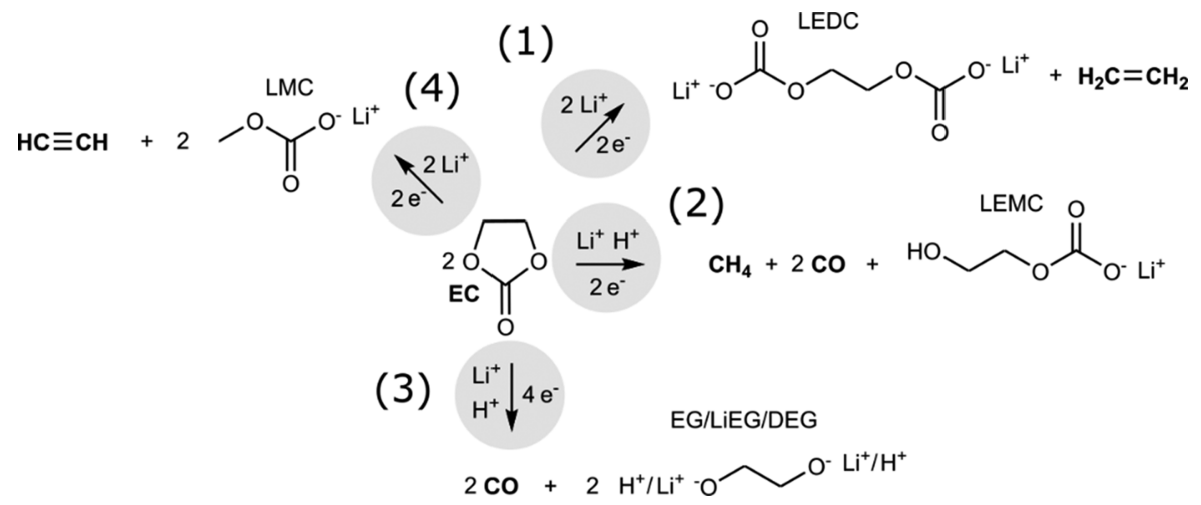

Figure 6. Proposed pathways for evolution of electrochemically evolved gas species detected herein resulting from EC reduction. EG, LiEG, and DEG correspond to $\mathrm{HOCH}_{2} \mathrm{CH}_{2} \mathrm{OH}, \mathrm{HOCH}_{2} \mathrm{CH}_{2} \mathrm{OLi}$, and $\mathrm{LiOCH}_{2} \mathrm{CH}_{2} \mathrm{OLi}$, respectively.

Like $\mathrm{CO}_{2}, \mathrm{H}_{2}$ is also evolved in major quantities (Figure 1) and is largely insensitive to current density (Figure 4). This is consistent with the expected result that $\mathrm{H}_{2}$ evolves by a facile chemical reaction of freshly plated $\mathrm{Li}$ with $\mathrm{HF}$ and/or $\mathrm{H}_{2} \mathrm{O}$, a chemical reaction, forming lithium fluoride $(\mathrm{LiF})$ and/or hydroxide $(\mathrm{LiOH})$ and releasing $\mathrm{H}_{2}$, rather than a result of the electrochemical solvent reduction. We note that similar polarization-activated $\mathrm{H}_{2}$ evolution was also observed in electrolyte systems containing $\mathrm{LiTFSI}$ and $\mathrm{LiClO}_{4}$ (Figure S10), and hence the chemical evolution of $\mathrm{H}_{2}$ is not linked to the salt species in the electrolyte, unlike $\mathrm{CO}_{2}$. However, the source of protons in electrolytes with $\mathrm{LiPF}_{6}$ and LiTFSI/ $\mathrm{LiClO}_{4}$ is different. Using Karl Fischer titration and ${ }^{1} \mathrm{H}$ and ${ }^{19} \mathrm{~F}$ NMR (Figure S11), ${ }^{39,42}$ we confirmed that $\mathrm{H}_{2} \mathrm{O}$ fully hydrolyzes $\mathrm{LiPF}_{6}$ and forms $\mathrm{HF}^{42}$ and hence the latter is likely the source of protons in a $\mathrm{LiPF}_{6}$-rich electrolyte.

Electrochemical Reaction Pathways in EC/DMC Deduced from Operando GC Measurements. Based on our results along with previous understanding of SEI-forming chemistry on $\mathrm{Li}^{15,16,24,34}$ we here interpret gas evolution data to suggest pathways through which the observed gases quantitatively form under electrochemical conditions in EC/ DMC. First, note that, as mentioned previously, DMC can be ruled out as a major participant due to lack of ethane-a key product of DMC decomposition-and in agreement with previous studies. ${ }^{12,18,43}$ Figure 6 therefore presents the most probable candidate EC decomposition pathways due to their consistency with gas measurements herein and previously reported solid-phase results. Several other previously suggested electrolyte decomposition reactions to which we have found no evidence, along with hypothetical DMC decomposition reactions, are included for completeness in Table S3 along with rationale for their exclusion.

Out of all possible mechanisms, four pathways involve electrochemical reduction of EC and agree qualitatively with the gases detected herein:

(1) Single-electron reduction of two EC molecules and reaction with two $\mathrm{Li}^{+}$, forming LEDC $\left(\mathrm{LiO}_{2} \mathrm{COCH}_{2} \mathrm{CH}_{2} \mathrm{OCO}_{2} \mathrm{Li}\right)$ with release of one molecule of $\mathrm{C}_{2} \mathrm{H}_{4}$ :

$$
2 \mathrm{EC}+2 \mathrm{e}^{-}+2 \mathrm{Li}^{+} \rightarrow \mathrm{LEDC}+\mathrm{C}_{2} \mathrm{H}_{4}
$$

(2) Single-electron reduction of two EC molecules and reaction with one $\mathrm{Li}^{+}$and one $\mathrm{H}^{+}$, forming LEMC $\left(\mathrm{HOCH}_{2} \mathrm{CH}_{2} \mathrm{OCO}_{2} \mathrm{Li}\right)$. This corresponds to release of one molecule of $\mathrm{CH}_{4}$ and two molecules of $\mathrm{CO}$ :

$$
2 \mathrm{EC}+2 \mathrm{e}^{-}+\mathrm{Li}^{+}+\mathrm{H}^{+} \rightarrow \mathrm{LEMC}+2 \mathrm{CO}+\mathrm{CH}_{4}
$$

(3) Two-electron reduction of one EC molecule and reaction with two $\mathrm{Li}^{+}$, forming $\mathrm{CO}$ and dilithium ethylene glycolate (DEG), $\mathrm{LiOCH}_{2} \mathrm{CH}_{2} \mathrm{OLi}$; with $\mathrm{Li}^{+} / \mathrm{H}^{+}$, forming lithium ethylene glycolate ( $\mathrm{LiEG}), \mathrm{LiOCH}_{2} \mathrm{CH}_{2} \mathrm{OH}$; or with two $\mathrm{H}^{+}$, forming ethylene glycol (EG), $\mathrm{HOCH}_{2} \mathrm{CH}_{2} \mathrm{OH}$ :

$$
\begin{aligned}
& \mathrm{EC}+2 \mathrm{e}^{-}+2 \mathrm{Li}^{+} \rightarrow \mathrm{DEG}+\mathrm{CO} \\
& \mathrm{EC}+2 \mathrm{e}^{-}+\mathrm{Li}^{+}+\mathrm{H}^{+} \rightarrow \mathrm{LiEG}+\mathrm{CO} \\
& \mathrm{EC}+2 \mathrm{e}^{-}+2 \mathrm{H}^{+} \rightarrow \mathrm{EG}+\mathrm{CO}
\end{aligned}
$$

(4) Single-electron reduction of EC and formation of LMC $\left(\mathrm{CH}_{3} \mathrm{OCO}_{2} \mathrm{Li}\right)$ with release of one molecule of $\mathrm{C}_{2} \mathrm{H}_{2}$ :

$$
\mathrm{EC}+\mathrm{e}^{-}+\mathrm{Li}^{+} \rightarrow \mathrm{LMC}+\mathrm{C}_{2} \mathrm{H}_{2}
$$

Pathway (1) corresponds to the accepted mechanism for the formation of LEDC on graphite. ${ }^{11,24}$ Pathway (2) is a singleelectron reduction of EC and results in a partially decarbonylated solid-phase product, LEMC. Pathway (3) involves a two-electron reduction of a single $\mathrm{EC}$ molecule to form alkoxide, a competing EC reduction pathway that has been linked to $\mathrm{CO}$ evolution on graphite. Although this pathway is less well-accepted, density functional theory (DFT) calculations by Leung ${ }^{44}$ have suggested it may be more thermodynamically favorable than single-electron reactions. Pathways that require involvement of protons in the electrolyte, namely Pathways (2) and (3b,c), are also generally less discussed, perhaps based on assumptions that battery electrolytes are highly aprotic. However, even $\sim 10 \mathrm{ppm}$ of $\mathrm{H}_{2} \mathrm{O}$ yields $280 \mathrm{nmol}$ of $\mathrm{H}^{+}$in $250 \mu \mathrm{L}$ of electrolyte, enough to drive Pathway (2), which requires $\sim 20 \mathrm{nmol} \mathrm{H}^{+}$based on Figure 1. Finally, the detection of $\mathrm{C}_{2} \mathrm{H}_{2}$, with a likely Pathway (4), suggests the prior formation of $\mathrm{CH}$ radicals that then react to form $\mathrm{C}_{2} \mathrm{H}_{2}$.

Among the above options, there is a unique decomposition mechanism consuming $\mathrm{H}^{+}$, i.e., Pathway (2), that yields two moles of $\mathrm{CO}$ for each mole of $\mathrm{CH}_{4}$, in good agreement with the observed gas ratios herein. For Li plating in EC/DMC, the $2: 1$ ratio is precisely met for current densities up to $3 \mathrm{~mA} /$ $\mathrm{cm}^{2}{ }_{\mathrm{Li}}$ in Figure 5a (note that a similar $\mathrm{CO} / \mathrm{CH}_{4}$ molar ratio was reported previously in cycled cells with graphite anodes, ${ }^{19}$ though neither the underlying stoichiometry nor pathway were explicitly discussed). Thus, Pathway (2) fully accounts for all $\mathrm{CO}$ and $\mathrm{CH}_{4}$ gas evolution at low-to-moderate current densities on $\mathrm{Li}$. $\mathrm{C}_{2} \mathrm{H}_{4}$, associated with formation of LEDC, 
forms via Pathway (1). Up to $1 \mathrm{~mA} / \mathrm{cm}^{2}{ }_{\mathrm{Lig}} \mathrm{C}_{2} \mathrm{H}_{4}$ is evolved at a proportion of $\mathrm{C}_{2} \mathrm{H}_{4} / \mathrm{CH}_{4}=1$ (Figure $5 \mathrm{~b}$ ) and then proportionally increases thereafter. Therefore, the branching between Pathways (1) and (2) is $1: 1$ up to $1 \mathrm{~mA} / \mathrm{cm}^{2}$, with Pathway (1) becoming more dominant at higher rates (branching ratio up to $2.5: 1$ at currents $\geq 2 \mathrm{~mA} / \mathrm{cm}^{2}$ ). This kinetic selectivity toward Pathway (1) at high rates can be rationalized by the limited availability of $\mathrm{H}^{+}$, required for Pathway (2) but not in Pathway (1), which only consumes $\mathrm{Li}^{+}$ that are available in abundance. Note that this implies a transition from an equally LEMC/LEDC-rich SEI at low/ moderate rates to one that is increasingly dominated by LEDC at higher rates, a hypothesis that may be tested in future experimental studies of the solid-phase constituents of the $\mathrm{Li}$ SEI. At $4 \mathrm{~mA} / \mathrm{cm}^{2}$, it appears that an additional pathway for the formation of $\mathrm{CO}$ becomes active, e.g., Pathway (3), given the sharp uptick in the $\mathrm{CO} / \mathrm{CH}_{4}$ ratio. Based on the low amount of $\mathrm{C}_{2} \mathrm{H}_{2}$ observed, Pathway (4) is largely inactive regardless of current density.

Interestingly, previous studies on graphite have identified significant quantities of LEMC and LMC in the SEI using solution NMR analyses after the formation cycle. ${ }^{15}$ It was then suggested by ex situ chemical synthesis that these phases can result from two possible processes that may occur within actively cycling cells: chemical reactions involving LEDC as a metastable phase which then reacts with DMC or water to yield LEMC or LMC or nucleophilic addition of $\mathrm{OH}^{-} / \mathrm{MeO}^{-}$ groups to EC. ${ }^{15}$ Note that the former implies exclusive $\mathrm{C}_{2} \mathrm{H}_{4}$ formation with no $\mathrm{CO}, \mathrm{CH}_{4}$, or $\mathrm{C}_{2} \mathrm{H}_{2}$, whereas the latter would result in no gas evolution. Our results, which found evidence of $\mathrm{CO}$ and $\mathrm{CH}_{4}$ and in amounts similar to $\mathrm{C}_{2} \mathrm{H}_{4}$, indicate that the first pathway does not occur exclusively on $\mathrm{Li}$. Rather, LEMC-which forms alongside $\mathrm{CO}$ and $\mathrm{CH}_{4}$ through Pathway (2) in a current-dependent manner-can be formed directly by electrochemical EC reduction, without progression through LEDC. Otherwise, much higher proportions of $\mathrm{C}_{2} \mathrm{H}_{4}$ would be expected. Therefore, while the LEDC-forming mechanism, i.e., Pathway (1), has been thought to be the dominant reaction for SEI formation, ${ }^{11,15,24}$ our results suggest that, at least at low current densities on $\mathrm{Li}$, a direct-LEMCforming reaction, i.e., Pathway (2), is equally active.

Effect of the Electrolyte Salt Anion. We next investigated whether the electrolyte salt influences the pathways through which EC reduction occurs. Symmetric Lill $\mathrm{Li}$ cells were assembled in EC/DMC with $1 \mathrm{M}$ salt: $\mathrm{LiPF}_{6}$, $\mathrm{LiClO}_{4}$, or LiTFSI. As before, gases were monitored over a galvanostatic half-cycle at a low rate of $0.5 \mathrm{~mA} / \mathrm{cm}_{\mathrm{Li}}^{2}$ to a capacity of $1.5 \mathrm{mAh} / \mathrm{cm}_{\mathrm{Li}}^{2}$ (Figure $7 \mathrm{a}$, Figure $\mathrm{S} 10$ ). The subsequent analysis focuses on the electrochemically formed gases in $\mathrm{LiPF}_{6}$, namely, $\mathrm{CH}_{4}, \mathrm{C}_{2} \mathrm{H}_{4}, \mathrm{C}_{2} \mathrm{H}_{2}$, and $\mathrm{CO}$ (as reported already, no significant $\mathrm{CO}_{2}$ was evolved with LiTFSI and $\mathrm{LiClO}_{4}$ above the baseline). In general, both LiTFSI and $\mathrm{LiClO}_{4}$ systems evolved slightly more of these gases during the initial half-cycle than with $\mathrm{LiPF}_{6}$. With LiTFSI, the specific gases $\mathrm{C}_{2} \mathrm{H}_{2}, \mathrm{CH}_{4}$, and $\mathrm{C}_{2} \mathrm{H}_{4}$ were evolved at comparable rates as in $\mathrm{LiPF}_{6}\left(\sim 0.005, \sim 0.11\right.$, and $\sim 0.12 \mathrm{nmol} / \mathrm{min} / \mathrm{cm}^{2}$ ij respectively); thus, the major difference was the ratio of $\mathrm{CO} /$ $\mathrm{CH}_{4}$, which was $\sim 5: 1$ compared to a ratio of $2: 1$ in $\mathrm{LiPF}_{6}$ (Figure $7 \mathrm{~b}$ ). With $\mathrm{LiClO}_{4}$, the $\mathrm{CO} / \mathrm{CH}_{4}$ ratio was yet higher at $\sim 10: 1$. In addition, the molar ratio of $\mathrm{C}_{2} \mathrm{H}_{4} / \mathrm{CH}_{4}$ increased over time with $\mathrm{LiClO}_{4}$ (Figure 7c), from a low amount comparable to the other two salts $(\sim 0.3)$ to a significantly higher amount $(\sim 2.8)$ after $3 \mathrm{~h}$. We note that this is due to a
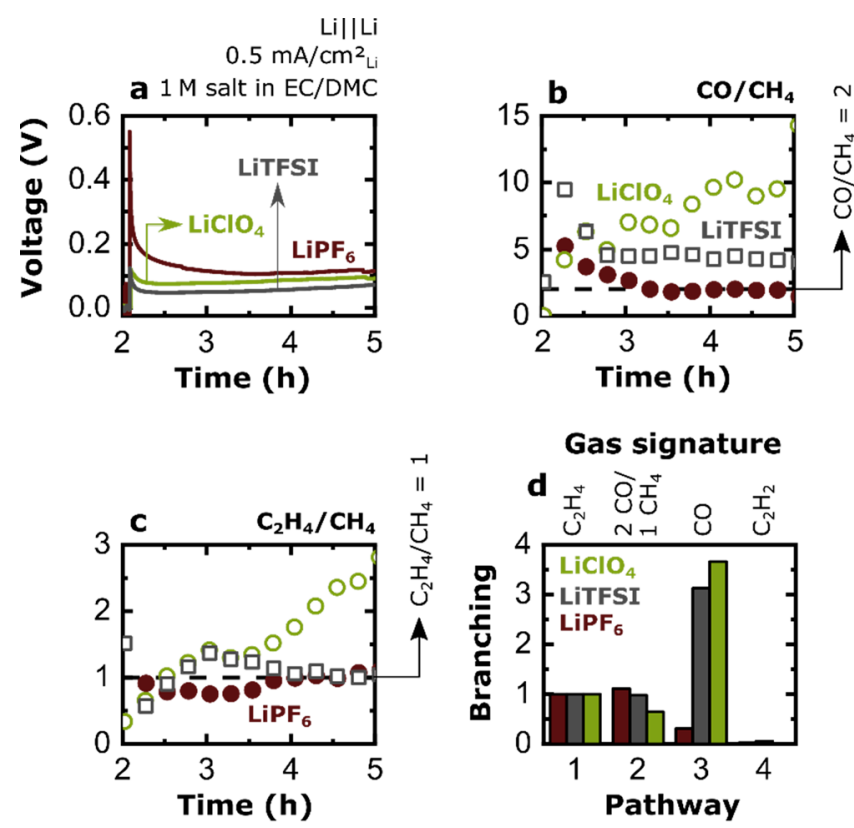

Figure 7. (a) Potential vs time of a symmetric LillLi cell with $1 \mathrm{M}$ $\mathrm{LiClO}_{4}, 1 \mathrm{M} \mathrm{LiPF}$, or $1 \mathrm{M}$ LiTFSI in EC/DMC during a galvanostatic half cycle at $0.5 \mathrm{~mA} / \mathrm{cm}^{2}{ }_{\mathrm{Li}}$ to a capacity of $1.5 \mathrm{mAh}$ / $\mathrm{cm}_{\mathrm{Li}}^{2}$. (b, c) Molar ratios of the major electrochemically evolved species, i.e., (b) $\mathrm{CO} / \mathrm{CH}_{4}$ and (c) $\mathrm{C}_{2} \mathrm{H}_{4} / \mathrm{CH}_{4}$. (d) Relative branching of the proposed reaction pathways (Figure 6) based on the observed mean gas evolution rates (Figure S10).

decrease in the amount of $\mathrm{CH}_{4}$ evolution over this time, rather than a quantitative increase in $\mathrm{C}_{2} \mathrm{H}_{4}$, which was steady (Figure $\mathrm{S} 10)$, although the underlying cause is not currently known. Regardless, the main difference between $\mathrm{LiClO}_{4}$ and other salts is the much higher rate of $\mathrm{CO}$ evolution. Because $\mathrm{CO}$ is the major electrochemically formed gas evolved with LiTFSI and $\mathrm{LiClO}_{4}$, Pathway (3) - which generates only $\mathrm{CO}$ - dominates SEI reactions in these systems, rather than Pathway (2), which coevolves $\mathrm{CH}_{4}$ as observed previously with $\mathrm{LiPF}_{6}$. Overall, it can be deduced from Figures 6 and 7 that the branching ratios among Pathways (1)-(4) are highly salt-dependent, being approximately 1:1:4:0.01 for $\mathrm{LiClO}_{4}, 1: 1: 3: 0.05$ for LiTFSI, and 1:1:0.3:0.02 for $\mathrm{LiPF}_{6}$, as illustrated in Figure $7 \mathrm{~d}$. In other words, "pure" $\mathrm{CO}$ evolution dominates the behavior with the non-LiPF 6 salts, i.e., through Pathway (3), at the expense of the other reaction pathways.

The observed salt-induced shift in reaction pathways can be rationalized by looking at the solvation structures of $\mathrm{LiPF}_{6}$, LiTFSI, and $\mathrm{LiClO}_{4}$ in carbonate electrolytes. Density functional theory calculations have shown that the formation of contact-ion pairs are much less thermodynamically favorable in $\mathrm{LiPF}_{6}$ - than in $\mathrm{LiClO}_{4^{-}}$or LiTFSI-containing carbonate electrolytes. ${ }^{45,46}$ Hence, in LiTFSI and $\mathrm{LiClO}_{4}, \mathrm{Li}^{+}$is statistically more likely to be coordinated with the anion at the expense of the solvent molecules, implying a relatively solvent-poor solvation sphere in these systems. In contrast, $\mathrm{Li}^{+}$ in $\mathrm{LiPF}_{6}$ is more likely to be fully solvated by carbonate molecules. Therefore, electrolyte salts that lower the solvent availability in the solvation sphere of $\mathrm{Li}^{+}$appear to- somewhat counterintuitively-facilitate decarbonylation pathways, consistent with our observation of increased $\mathrm{CO}$ evolution in LiTFSI and $\mathrm{LiClO}_{4}$ systems. Future computational efforts will be helpful to verify and study this trend in greater detail. 


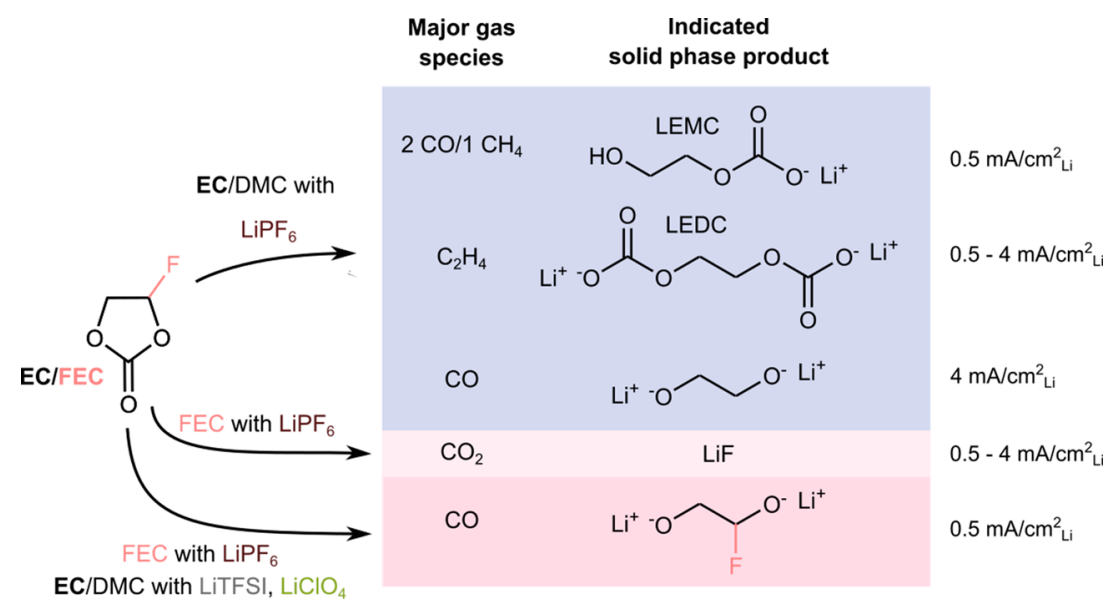

Figure 8. Summary of the hypothesized active electrochemical pathways under conditions investigated herein, namely, current density, electrolyte salt, and solvent fluorination.

Effect of Solvent Fluorination. Given the implication of electrochemical solvent reduction in the SEI repair process, we extended the study to probe the effect of solvent fluorination. Fluorinated solvents are an emerging motif in electrolyte development for high-voltage and high-energy battery chemistries given reported improvements in Coulombic efficiency of $\mathrm{Li}$ plating/stripping ${ }^{47}$ along with enhanced electrolyte stability. ${ }^{48}$ As a representative fluorinated species, FEC was selected due to its molecular similarity, corresponding to an EC molecule with a single fluorine-substituted hydrogen. Moreover, despite its widespread use as an electrolyte additive, ${ }^{47,49}$ relatively little is known about gases released upon FEC reduction. The results for cumulative, operando, and current density-dependent gas evolution are shown alongside those of EC/DMC in Figures 1, 2, and 4, respectively, for the $1 \mathrm{M} \mathrm{LiPF}_{6}$ salt. Among all gases evolved, $\mathrm{CO}_{2}$ was the major product evolved in FEC, as with $\mathrm{EC} /$ DMC. However, the quantity of $\mathrm{CO}_{2}$ evolved was significantly lower $\left(93 \mathrm{nmol} / \mathrm{cm}_{\mathrm{Li}}^{2}\right.$ ) compared to EC/DMC (Figure 1), followed by the likewise decreased formation of $\mathrm{CO}(6.8$ $\left.\mathrm{nmol} / \mathrm{cm}_{\mathrm{Li}}^{2}\right), \mathrm{CH}_{4}\left(2.97 \mathrm{nmol} / \mathrm{cm}_{\mathrm{Li}}^{2}\right)$, and $\mathrm{C}_{2} \mathrm{H}_{2}(7 \mathrm{pmol} /$ $\mathrm{cm}_{\mathrm{Li}}^{2}$ ). Although previous studies on FEC reduction are scarcer relative to those in the more conventional carbonates, $\mathrm{CO}_{2}$ was previously hypothesized, ${ }^{49}$ via the reaction $\mathrm{FEC}+\mathrm{e}^{-}$ $+\mathrm{Li}^{+} \rightarrow \mathrm{LiF}+\mathrm{CO}_{2}+{ }^{\circ} \mathrm{CH}_{2} \mathrm{CHO},{ }^{50}$ and later confirmed ${ }^{51}$ to be a major product of FEC reduction on graphite anodes. $\mathrm{CO}$, on the other hand, had only been previously detected in trace amounts at reducing potentials $\left(<0.5 \mathrm{~V}\right.$ vs $\left.\mathrm{Li} / \mathrm{Li}^{+}\right)$on graphite. ${ }^{51}$ Direct evidence for $\mathrm{CH}_{4}$ and $\mathrm{C}_{2} \mathrm{H}_{2}$ evolution have not been previously reported in FEC to the best of our knowledge, including in theoretical calculations. ${ }^{51-53}$ In general, the observation of suppressed overall gas evolution with FEC-indicating lower reactivity of this electrolyte-is consistent with current empirical understanding that fluorinated solvents support formation of more stable interphases with improved Coulombic efficiencies, discussed further below. ${ }^{48}$

In contrast to EC/DMC, $\mathrm{C}_{2} \mathrm{H}_{4}$ was not detected with FEC. The lack of $\mathrm{C}_{2} \mathrm{H}_{4}$ implies that either a mechanism similar to Pathway (1) is not active for FEC reduction or that the evolved gases contain fluorinated equivalent species (i.e., $\mathrm{C}_{2} \mathrm{H}_{2} \mathrm{~F}_{2}$ or $\mathrm{C}_{2} \mathrm{H}_{3} \mathrm{~F}$ ) not detectable by $\mathrm{GC}$ alone. To investigate the latter possibility, a gas sample was extracted from the cell headspace after plating and was subjected to GC/MS analysis
(Figure S12a). The GC/MS experiments confirmed the results shown in Figure 1, namely, that $\mathrm{CO}(\mathrm{m} / z=28)$ and $\mathrm{CO}_{2}(\mathrm{~m} / z$ $=44)$ are the major gases formed during plating/stripping in FEC solvent. There was also a lack of counts detected in the $m / z=40-80$ range (Figure S12b), where most of the simple fluorinated hydrocarbons like $\mathrm{C}_{2} \mathrm{H}_{3} \mathrm{~F} / \mathrm{C}_{2} \mathrm{H}_{2} \mathrm{~F}_{2}$ and their fragments are expected. ${ }^{54}$ Ruling out this option, we can conclude that a Pathway (1)-like mechanism, generating fluorinated analogues of $\mathrm{C}_{2} \mathrm{H}_{4}$, is not occurring here. Instead, reduced FEC species likely remain in the liquid phase or are incorporated into the SEI, rather than being liberated to the gas phase.

As in $\mathrm{EC} / \mathrm{DMC}, \mathrm{CO}$ and $\mathrm{CH}_{4}$ exhibited evolution rates that were linearly dependent on the applied current in FEC (Figure 4). Their ratio, $\mathrm{CO} / \mathrm{CH}_{4} \approx 5-15$, was much higher than the observed 2:1 in EC/DMC through Pathway (2), suggesting enhancement of a mechanism that involves CO release. A possible candidate is one analogous to Pathway (3), forming a fluorinated dialkoxide $\left({ }^{-} \mathrm{OCHFCH} \mathrm{O}_{2}{ }^{-}\right)$alongside. Critically, $\mathrm{CO}_{2}$ - which did not display current dependence in $\mathrm{EC} /$ DMC-did exhibit linear current dependence in FEC. This finding is consistent with the reaction on graphite mentioned above, i.e., $\mathrm{FEC}+\mathrm{e}^{-}+\mathrm{Li}^{+} \rightarrow \mathrm{LiF}+\mathrm{CO}_{2}+{ }^{\bullet} \mathrm{CH}_{2} \mathrm{CHO}$, which provides for an electron-driven $\mathrm{CO}_{2}$ evolution pathway. More broadly, the major gases observed, namely, $\mathrm{CO}_{2}$ and $\mathrm{CO}$, combined with the higher $\mathrm{CO} / \mathrm{CH}_{4}$ ratios indicate that, unlike EC, FEC is more effectively decarbonylated/decarboxylated upon reduction, implying suppressed semicarbonate accumulation in the SEI. Instead, the interphase is likely rich in fluorine, as other studies have identified. ${ }^{49}$ Overall, Figure 8 summarizes the major gas species observed under each condition along with their implied solid-phase side products.

Interestingly, the evolved gas signatures were found to relate directly to the obtainable Coulombic efficiencies upon $\mathrm{Li}$ plating/stripping in the respective electrolytes. Figure 9a shows the Coulombic efficiencies over the first 25 cycles in asymmetric CullLi cells, obtained by plating to a capacity of $1 \mathrm{mAh} / \mathrm{cm}^{2}$ ai and then stripping to a cutoff of $2 \mathrm{~V}$ at $0.5 \mathrm{~mA} /$ $\mathrm{cm}_{\mathrm{Li}}^{2}$. For $1 \mathrm{M} \mathrm{LiPF}_{6}$ in EC/DMC, despite an increase in cell efficiency over the initial cycles to a maximum of $\sim 93 \%$, the Coulombic efficiency degraded steeply from the fifth cycle onward. Switching the salt to $\mathrm{LiClO}_{4}$ led to higher and stable Coulombic efficiencies of $~ 93 \%$; meanwhile, the best performance was obtained with the fluorinated electrolyte, $1 \mathrm{M} \mathrm{LiPF}_{6}$ 

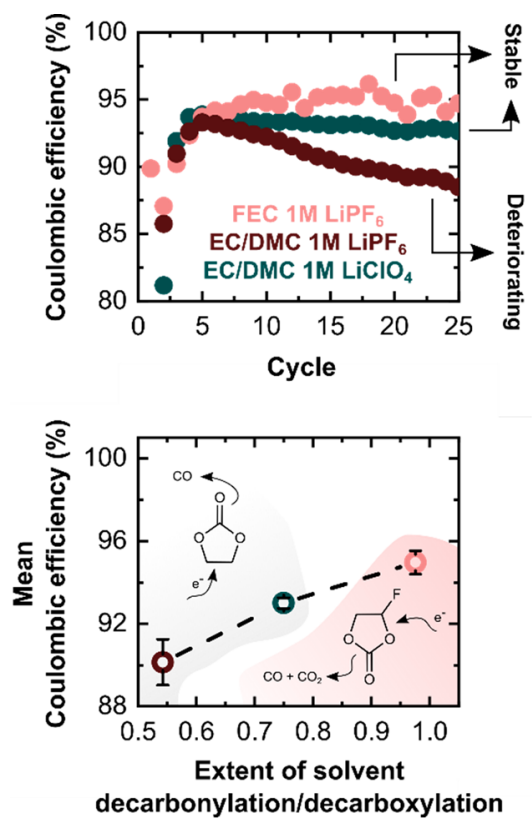

Figure 9. Plating/stripping Coulombic efficiency of LillCu cells with 1 $\mathrm{M} \mathrm{LiPF}_{6}$ in EC/DMC or FEC and $1 \mathrm{M} \mathrm{LiClO}_{4}$ in EC/DMC cycled at a current density of $0.5 \mathrm{~mA} / \mathrm{cm}^{2}$ to a capacity of $1 \mathrm{mAh} / \mathrm{cm}^{2}{ }_{\mathrm{Li}}$. (b) Mean Coulombic efficiency over the last 15 cycles as a function of the extent of solvent electrochemical decarbonylation/decarboxylation upon reduction (defined in the text).

in FEC, with stable Coulombic efficiencies of 95\%. As shown in Figure 8, both FEC and use of a $\mathrm{LiClO}_{4}$-based electrolyte led to expressive $\mathrm{CO}$ evolution. As discussed previously, $\mathrm{CO}$ release results from the decarbonylation of $\mathrm{EC}$ or FEC, leaving an alkoxy-based SEI, i.e., dominated by LiOROLi species. In addition, FEC was distinguished by electrochemically activated $\mathrm{CO}_{2}$ evolution, suggesting loss of $-\mathrm{COO}$ (decarboxylation) as solvent was consumed to repair the SEI. We therefore defined and calculated a candidate descriptor based on the extent of electrochemical decarbonylation/decarboxylation of solvent, i.e., the rate of gases evolved for which the solvent loses the carbonate functional group upon reduction ( $\mathrm{CO}$ for EC/DMC and $\mathrm{CO}+\mathrm{CO}_{2}$ for FEC) per total rate of gases formed electrochemically ( $\mathrm{CO}+\mathrm{CH}_{4}+\mathrm{C}_{2} \mathrm{H}_{4}+\mathrm{C}_{2} \mathrm{H}_{2}$ for EC/DMC and $\mathrm{CO}+\mathrm{CO}_{2}+\mathrm{CH}_{4}$ for FEC). Figure $9 \mathrm{~b}$ shows that there is a strong and linearly increasing relationship between the reduction of carbonate groups in the SEI and Coulombic efficiency. For example, FEC, for which the extent of decarbonylation/decarboxylation is $\sim 0.97$ (meaning nearly all electrochemically formed gases generated are $\mathrm{CO}_{2}$ or $\mathrm{CO}$ ), displays a mean Coulombic efficiency of $95 \%$.

Whereas conventional wisdom has recently highlighted ionic phases, and specifically $\mathrm{LiF}$, as a possible favorable phase for a "good" SEI (a topic of current debate and ongoing study), ${ }^{9}$ our results suggest another descriptor-degree of decarbonylation/ decarboxylation-in the SEI as correlating strongly with SEI quality and thus Coulombic efficiency. Promisingly, this descriptor has simple gas signatures that can be measured over a single plating cycle, rather than relying on timeconsuming, long-term cycling, as is current best practice. Extension of these studies to a broader range of electrolyte systems in future work will continue to elucidate and test the link between this metric and cycling performance indexes. Overall, these results reveal that there is rich information yet to be gleaned about the subtleties of SEI-forming, dynamic processes on $\mathrm{Li}$, and that understanding the SEI-formation mechanisms - and chemical/electrochemical factors that modulate them-can point toward promising chemical strategies to directly improve Li performance.

\section{CONCLUSION}

A custom operando GC configuration was used to quantify gases evolved from SEI-repair reactions during cycling of symmetric LillLi cells. The operando nature of the experiments enabled identification of specific pathways that lead to the evolution of $\mathrm{CO}, \mathrm{CH}_{4}, \mathrm{C}_{2} \mathrm{H}_{4}$, and $\mathrm{C}_{2} \mathrm{H}_{2}$, of which well-known solid phase SEI components (LEMC, LMC, and LEDC) are likely side products. These interphasial gas-forming reactions are, as shown herein, electrochemical-and not chemical-in nature and occur almost exclusively during the plating halfcycle, rather than during $\mathrm{Li}$ stripping. After their formation cycle, a carbonate-based SEI was shown to continuously chemically react with a $\mathrm{LiPF}_{6}$-containing electrolyte, releasing $\mathrm{CO}_{2}$. The electrochemical reactions through which the interphase is formed were then shown to be rationally selectable. FEC-, $\mathrm{LiClO}_{4^{-}}$, and LiTFSI-containing electrolytes are more likely to promote decarbonylation/decarboxylation of the solvent during electrochemical reduction, releasing $\mathrm{CO}$ and likely an accompanying alkoxy side product in a condensed phase. Coulombic efficiency measurements over multiple cycles in CullLi half-cells showed that solvents that effectively lose their carbonate functional group by releasing $\mathrm{CO}$ or $\mathrm{CO}_{2}$ upon solvent reduction also display better cycling stability. Hopefully, the demonstrated ability to select toward specific organic SEI components during its in situ formation will provide a framework to further investigate the role of specific solid phase compounds and identify improved Li SEI compositions for optimized stability and long-term cycling.

\section{ASSOCIATED CONTENT}

\section{Supporting Information}

The Supporting Information is available free of charge at https://pubs.acs.org/doi/10.1021/acs.chemmater.9b04550.

Additional figures, tables, references, and discussion on evaluation of water content in the tested cells, chemical evolution of $\mathrm{CO}_{2}$, NMR of the electrolyte, MS measurements of the cell headspace, and extended electrochemical and gas-evolution data for rate-dependent and salt-dependent measurements (PDF)

\section{AUTHOR INFORMATION}

\section{Corresponding Author}

Betar M. Gallant - Department of Mechanical Engineering, Massachusetts Institute of Technology, Cambridge,

Massachusetts 02139, United States; 이이.org/0000-00024586-2769

\section{Authors}

Gustavo M. Hobold - Department of Mechanical Engineering, Massachusetts Institute of Technology, Cambridge, Massachusetts 02139, United States; 이이. orcid.org/0000-00016749-3370

Aliza Khurram - Department of Mechanical Engineering, Massachusetts Institute of Technology, Cambridge, Massachusetts 02139, United States; 이이.org/0000-00027758-9314 
Complete contact information is available at:

https://pubs.acs.org/10.1021/acs.chemmater.9b04550

\section{Notes}

The authors declare no competing financial interest.

\section{ACKNOWLEDGMENTS}

Funding by the MIT Department of Mechanical Engineering is gratefully acknowledged.

\section{REFERENCES}

(1) Lin, D.; Liu, Y.; Cui, Y. Reviving the Lithium Metal Anode for High-Energy Batteries. Nat. Nanotechnol. 2017, 12 (3), 194.

(2) Xu, W.; Wang, J.; Ding, F.; Chen, X.; Nasybulin, E.; Zhang, Y.; Zhang, J.-G. Lithium Metal Anodes for Rechargeable Batteries. Energy Environ. Sci. 2014, 7 (2), 513-537.

(3) Peled, E.; Menkin, S. SEI: Past, Present and Future. J. Electrochem. Soc. 2017, 164 (7), A1703-A1719.

(4) $\mathrm{Xu}, \mathrm{K}$. Nonaqueous Liquid Electrolytes for Lithium-Based Rechargeable Batteries. Chem. Rev. 2004, 104 (10), 4303-4418.

(5) Peled, E.; Golodnitsky, D.; Ardel, G. Advanced Model for Solid Electrolyte Interphase Electrodes in Liquid and Polymer Electrolytes. J. Electrochem. Soc. 1997, 144 (8), L208-L210.

(6) Tikekar, M. D.; Choudhury, S.; Tu, Z.; Archer, L. A. Design Principles for Electrolytes and Interfaces for Stable Lithium-Metal Batteries. Nature Energy 2016, 1 (9), 16114.

(7) $\mathrm{Xu}, \mathrm{K}$. Electrolytes and Interphases in Li-Ion Batteries and Beyond. Chem. Rev. 2014, 114 (23), 11503-11618.

(8) Chen, L.; Fan, X.; Hu, E.; Ji, X.; Chen, J.; Hou, S.; Deng, T.; Li, J.; Su, D.; Yang, X.; Wang, C. Achieving High Energy Density through Increasing the Output Voltage: A Highly Reversible $5.3 \mathrm{~V}$ Battery. Chem. 2019, 5 (4), 896-912.

(9) Suo, L.; Xue, W.; Gobet, M.; Greenbaum, S. G.; Wang, C.; Chen, Y.; Yang, W.; Li, Y.; Li, J. Fluorine-Donating Electrolytes Enable Highly Reversible 5-V-Class Li Metal Batteries. Proc. Natl. Acad. Sci. U. S. A. 2018, 115 (6), 1156-1161.

(10) Gauthier, M.; Carney, T. J.; Grimaud, A.; Giordano, L.; Pour, N.; Chang, H.-H.; Fenning, D. P.; Lux, S. F.; Paschos, O.; Bauer, C.; Maglia, F.; Lupart, S.; Lamp, P.; Shao-Horn, Y. Electrode-Electrolyte Interface in Li-Ion Batteries: Current Understanding and New Insights. J. Phys. Chem. Lett. 2015, 6 (22), 4653-4672.

(11) Heiskanen, S. K.; Kim, J.; Lucht, B. L. Generation and Evolution of the Solid Electrolyte Interphase of Lithium-Ion Batteries. Joule 2019, 3 (10), 2322-2333.

(12) Aurbach, D.; Ein-Ely, Y.; Zaban, A. The Surface Chemistry of Lithium Electrodes in Alkyl Carbonate Solutions. J. Electrochem. Soc. 1994, 141 (1), L1.

(13) Aurbach, D.; Chusid, O. The Study of Surface Films Formed on Lithium and Noble Metal Electrodes in Polar Aprotic Systems By the Use of In Situ Fourier Transform Infrared Spectroscopy. J. Electrochem. Soc. 1993, 140 (1), L1-L4.

(14) Aurbach, D.; Gofer, Y.; Ben-Zion, M.; Aped, P. The Behaviour of Lithium Electrodes in Propylene and Ethylene carbonate: The Major Factors that Influence Li Cycling Efficiency. J. Electroanal. Chem. 1992, 339 (1), 451-471.

(15) Wang, L.; Menakath, A.; Han, F.; Wang, Y.; Zavalij, P. Y.; Gaskell, K. J.; Borodin, O.; Iuga, D.; Brown, S. P.; Wang, C.; Xu, K.; Eichhorn, B. W. Identifying the Components of the Solid-Electrolyte Interphase in Li-Ion Batteries. Nat. Chem. 2019, 11 (9), 789-796.

(16) Mogi, R.; Inaba, M.; Iriyama, Y.; Abe, T.; Ogumi, Z. Study on the Decomposition Mechanism of Alkyl Carbonate on Lithium Metal by Pyrolysis-Gas Chromatography-Mass Spectroscopy. J. Power Sources 2003, 119, 597-603.

(17) Kominato, A.; Yasukawa, E.; Sato, N.; Ijuuin, T.; Asahina, H.; Mori, S. Analysis of Surface Films on Lithium in Various Organic Electrolytes. J. Power Sources 1997, 68 (2), 471-475.

(18) Dedryvère, R.; Gireaud, L.; Grugeon, S.; Laruelle, S.; Tarascon, J. M.; Gonbeau, D. Characterization of Lithium Alkyl Carbonates by
X-ray Photoelectron Spectroscopy: Experimental and Theoretical Study. J. Phys. Chem. B 2005, 109 (33), 15868-15875.

(19) Shin, J.-S.; Han, C.-H.; Jung, U.-H.; Lee, S.-I.; Kim, H.-J.; Kim, K. Effect of $\mathrm{Li}_{2} \mathrm{CO}_{3}$ Additive on Gas Generation in Lithium-Ion Batteries. J. Power Sources 2002, 109 (1), 47-52.

(20) Kumai, K.; Miyashiro, H.; Kobayashi, Y.; Takei, K.; Ishikawa, R. Gas Generation Mechanism Due to Electrolyte Decomposition in Commercial Lithium-Ion Cell. J. Power Sources 1999, 81-82, 715719.

(21) Ma, Y.; Feng, L.; Tang, C.-Y.; Ouyang, J.-H.; Dillon, S. J. Effects of Commonly Evolved Solid-Electrolyte-Interphase (SEI) Reaction Product Gases on the Cycle Life of Li-Ion Full Cells. J. Electrochem. Soc. 2018, 165 (13), A3084-A3094.

(22) La Mantia, F.; Novák, P. Online Detection of Reductive $\mathrm{CO}_{2}$ Development at Graphite Electrodes in the $1 \mathrm{M} \mathrm{LiPF}_{6}, \mathrm{EC}: \mathrm{DMC}$ Battery Electrolyte. Electrochem. Solid-State Lett. 2008, 11 (5), A84A87.

(23) Fang, C.; Li, J.; Zhang, M.; Zhang, Y.; Yang, F.; Lee, J. Z.; Lee, M.-H.; Alvarado, J.; Schroeder, M. A.; Yang, Y.; Lu, B.; Williams, N.; Ceja, M.; Yang, L.; Cai, M.; Gu, J.; Xu, K.; Wang, X.; Meng, Y. S. Quantifying Inactive Lithium in Lithium Metal Batteries. Nature 2019, 572 (7770), 511-515.

(24) Liu, T.; Lin, L.; Bi, X.; Tian, L.; Yang, K.; Liu, J.; Li, M.; Chen, Z.; Lu, J.; Amine, K.; Xu, K.; Pan, F. In Situ Quantification of Interphasial Chemistry in Li-Ion Battery. Nat. Nanotechnol. 2019, 14, $50-56$.

(25) Onuki, M.; Sakata, Y.; Yanagidate, M.; Otake, Y.; Kinoshita, S.; Ue, M.; Deguchi, M. Identification of the Source of Evolved Gas in LiIon Batteries by Using 13C-Labeled Solvents. ECS Trans. 2007, 11 (19), 43-47.

(26) Streich, D.; Guéguen, A.; Mendez, M.; Chesneau, F.; Novák, P.; Berg, E. J. Online Electrochemical Mass Spectrometry of High Energy Lithium Nickel Cobalt Manganese Oxide/Graphite Half- and FullCells with Ethylene Carbonate and Fluoroethylene Carbonate Based Electrolytes. J. Electrochem. Soc. 2016, 163 (6), A964-A970.

(27) Castel, E.; Berg, E. J.; El Kazzi, M.; Novák, P.; Villevieille, C. Differential Electrochemical Mass Spectrometry Study of the Interface of $\mathrm{xLi}_{2} \mathrm{MnO}_{3} \cdot(1-\mathrm{x}) \mathrm{LiMO}_{2}(\mathrm{M}=\mathrm{Ni}, \mathrm{Co}$, and $\mathrm{Mn})$ Material as a Positive Electrode in Li-Ion Batteries. Chem. Mater. 2014, 26 (17), 5051-5057.

(28) Lanz, P.; Sommer, H.; Schulz-Dobrick, M.; Novák, P. Oxygen Release from High-Energy $\mathrm{xLi}_{2} \mathrm{MnO}_{3} \cdot(1-\mathrm{x}) \mathrm{LiMO}_{2}(\mathrm{M}=\mathrm{Mn}, \mathrm{Ni}$, Co): Electrochemical, Differential Electrochemical Mass Spectrometric, In Situ Pressure, and In Situ Temperature Characterization. Electrochim. Acta 2013, 93, 114-119.

(29) Imhof, R.; Novák, P. Oxidative Electrolyte Solvent Degradation in Lithium-Ion Batteries: An In Situ Differential Electrochemical Mass Spectrometry Investigation. J. Electrochem. Soc. 1999, 146 (5), 17021702.

(30) Guéguen, A.; Streich, D.; He, M.; Mendez, M.; Chesneau, F. F.; Novák, P.; Berg, E. J. Decomposition of $\mathrm{LiPF}_{6}$ in High Energy Lithium-Ion Batteries Studied with Online Electrochemical Mass Spectrometry. J. Electrochem. Soc. 2016, 163 (6), A1095-A1100.

(31) Kong, W.; Li, H.; Huang, X.; Chen, L. Gas Evolution Behaviors for Several Cathode Materials in Lithium-Ion Batteries. J. Power Sources 2005, 142 (1-2), 285-291.

(32) Petibon, R.; Rotermund, L.; Nelson, K. J.; Gozdz, A. S.; Xia, J.; Dahn, J. R. Study of Electrolyte Components in Li Ion Cells Using Liquid-Liquid Extraction and Gas Chromatography Coupled with Mass Spectrometry. J. Electrochem. Soc. 2014, 161 (6), A1167-A1172.

(33) Gachot, G. g.; Ribière, P.; Mathiron, D.; Grugeon, S.; Armand, M.; Leriche, J.-B.; Pilard, S.; Laruelle, S. p. Gas Chromatography/ Mass Spectrometry As a Suitable Tool for the Li-Ion Battery Electrolyte Degradation Mechanisms Study. Anal. Chem. 2011, 83 (2), 478-485.

(34) Aurbach, D.; Zaban, A.; Ein-Eli, Y.; Weissman, I.; Chusid, O.; Markovsky, B.; Levi, M.; Levi, E.; Schechter, A.; Granot, E. Recent Studies on the Correlation Between Surface Chemistry, Morphology, Three-Dimensional Structures and Performance of $\mathrm{Li}$ and $\mathrm{Li}-\mathrm{C}$ 
Intercalation Anodes in Several Important Electrolyte Systems. J. Power Sources 1997, 68 (1), 91-98.

(35) Aurbach, D.; Markovsky, B.; Shechter, A.; Ein-Eli, Y.; Cohen, H. A Comparative Study of Synthetic Graphite and Li Electrodes in Electrolyte Solutions Based on Ethylene Carbonate-Dimethyl Carbonate Mixtures. J. Electrochem. Soc. 1996, 143 (12), 3809-3820.

(36) Marom, R.; Haik, O.; Aurbach, D.; Halalay, I. C. Revisiting $\mathrm{LiClO}_{4}$ as an Electrolyte for Rechargeable Lithium-Ion Batteries. J. Electrochem. Soc. 2010, 157 (8), A972-A983.

(37) Freunberger, S. A.; Chen, Y.; Peng, Z.; Griffin, J. M.; Hardwick, L. J.; Bardé, F.; Novák, P.; Bruce, P. G. Reactions in the Rechargeable Lithium- $\mathrm{O}_{2}$ Battery with Alkyl Carbonate Electrolytes. J. Am. Chem. Soc. 2011, 133 (20), 8040-8047.

(38) Gachot, G.; Grugeon, S.; Eshetu, G. G.; Mathiron, D.; Ribière, P.; Armand, M.; Laruelle, S. Thermal Behaviour of the LithiatedGraphite/Electrolyte Interface Through GC/MS Analysis. Electrochim. Acta 2012, 83, 402-409.

(39) Parimalam, B. S.; MacIntosh, A. D.; Kadam, R.; Lucht, B. L. Decomposition Reactions of Anode Solid Electrolyte Interphase (SEI) Components with $\mathrm{LiPF}_{6}$. J. Phys. Chem. C 2017, 121 (41), 22733-22738.

(40) Cresce, A. v.; Russell, S. M.; Baker, D. R.; Gaskell, K. J.; Xu, K. In Situ and Quantitative Characterization of Solid Electrolyte Interphases. Nano Lett. 2014, 14 (3), 1405-1412.

(41) Khurram, A.; Yin, Y.; Yan, L.; Zhao, L.; Gallant, B. M. The Governing Role of Solvent on Discharge Activity in Lithium- $\mathrm{CO}_{2}$ Batteries. J. Phys. Chem. Lett. 2019, 10 (21), 6679-6687.

(42) Stich, M.; Göttlinger, M.; Kurniawan, M.; Schmidt, U.; Bund, A. Hydrolysis of LiPF6 in Carbonate-Based Electrolytes for LithiumIon Batteries and in Aqueous Media. J. Phys. Chem. C 2018, 122 (16), $8836-8842$.

(43) Zhuang, G. V.; Yang, H.; Ross, P. N.; Xu, K.; Jow, T. R. Lithium Methyl Carbonate as a Reaction Product of Metallic Lithium and Dimethyl Carbonate. Electrochem. Solid-State Lett. 2006, 9 (2), A64-A68.

(44) Leung, K. Two-electron Reduction of Ethylene Carbonate: A Quantum Chemistry Re-Examination of Mechanisms. Chem. Phys. Lett. 2013, 568-569, 1-8.

(45) Ponnuchamy, V.; Mossa, S.; Skarmoutsos, I. Solvent and Salt Effect on Lithium Ion Solvation and Contact Ion Pair Formation in Organic Carbonates: A Quantum Chemical Perspective. J. Phys. Chem. C 2018, 122 (45), 25930-25939.

(46) Chapman, N.; Borodin, O.; Yoon, T.; Nguyen, C. C.; Lucht, B. L. Spectroscopic and Density Functional Theory Characterization of Common Lithium Salt Solvates in Carbonate Electrolytes for Lithium Batteries. J. Phys. Chem. C 2017, 121 (4), 2135-2148.

(47) Zhang, X.-Q.; Cheng, X.-B.; Chen, X.; Yan, C.; Zhang, Q. Fluoroethylene Carbonate Additives to Render Uniform Li Deposits in Lithium Metal Batteries. Adv. Funct. Mater. 2017, 27 (10), 1605989.

(48) Fan, X.; Chen, L.; Borodin, O.; Ji, X.; Chen, J.; Hou, S.; Deng, T.; Zheng, J.; Yang, C.; Liou, S. C.; Amine, K.; Xu, K.; Wang, C. Nonflammable Electrolyte Enables Li-Metal Batteries with Aggressive Cathode Chemistries. Nat. Nanotechnol. 2018, 13 (8), 715.

(49) Michan, A. L.; Parimalam, B. S.; Leskes, M.; Kerber, R. N.; Yoon, T.; Grey, C. P.; Lucht, B. L. Fluoroethylene Carbonate and Vinylene Carbonate Reduction: Understanding Lithium-Ion Battery Electrolyte Additives and Solid Electrolyte Interphase Formation. Chem. Mater. 2016, 28 (22), 8149-8159.

(50) Markevich, E.; Salitra, G.; Aurbach, D. Fluoroethylene Carbonate as an Important Component for the Formation of an Effective Solid Electrolyte Interphase on Anodes and Cathodes for Advanced Li-Ion Batteries. ACS Energy Letters 2017, 2 (6), 13371345.

(51) Schwenke, K. U.; Solchenbach, S.; Demeaux, J.; Lucht, B. L.; Gasteiger, $\mathrm{H}$. A. The Impact of $\mathrm{CO}_{2}$ Evolved from VC and FEC during Formation of Graphite Anodes in Lithium-Ion Batteries. J. Electrochem. Soc. 2019, 166 (10), A2035-A2047.
(52) Okuno, Y.; Ushirogata, K.; Sodeyama, K.; Tateyama, Y. Decomposition of the Fluoroethylene Carbonate Additive and the Glue Effect of Lithium Fluoride Products for the Solid Electrolyte Interphase: an Ab Initio Study. Phys. Chem. Chem. Phys. 2016, 18 (12), 8643-8653.

(53) Okamoto, Y. Decomposition Mechanism of Ethylene Carbonate and Fluoroethylene Carbonate Through Hydrogen Abstraction Under High Voltage Environment: An Ab-initio Study. J. Electrochem. Soc. 2014, 161 (10), A1527-A1533.

(54) Linstrom, P. J. L.; Mallard, W. G. NIST Chemistry WebBook, NIST Standard Reference Database Number 69; National Institute of Standards and Technology: Gaithersburg, MD, 2019. 